\title{
Performance Comparison among Multi-GNSS Single Frequency Precise Point Positioning Techniques
}

\author{
Anna INNAC1, , , Antonio ANGRISANO2, Salvatore GAGLIONE1, \\ Mario VULTAGGIO2 and Nicola CROCETTO3 \\ 1 Parthenope University of Naples, Department of Science and Technologies, Naples, Italy \\ anna.innac@uniparthenope.it, salvatore.gaglione@uniparthenope.it \\ 2 G. Fortunato University, Benevento, Italy \\ a.angrisano@unifortunato.eu, m.vultaggio@unifortunato.eu \\ ${ }^{3}$ Luigi Vanvitelli University of Campania, Department of Engineering, Naples, Italy \\ nicola.crocetto@unicampania.it \\ *Correspondence: anna.innac@uniparthenope.it
}

\begin{abstract}
Precise Point Positioning (PPP) is a technique able to compute high accuracy positioning anywhere using a single GNSS receiver and without the need for corrections from reference stations. A wide range of possible PPP algorithms, using different correction models and processing strategies, exist for both post-processing and real-time applications. PPP relies on accurate satellite and clock data, with the use of precise carrier-phase measurements. Single Frequency-PPP (SF-PPP) is currently under investigation by the scientific community, owing to its cheap implementation with respect to classical differential positioning and multi-frequency un-differenced techniques.

Unfortunately, the carrier-phase observable is ambiguous by an a priori unknown integer number of cycles, called ambiguity, which is difficult to resolve with SF receivers. The aim of this paper was to study the opportunity provided by the use of a multi-GNSS constellation applied to two widespread SF-PPP models, based on different carrier-phase and code observable combinations. The algorithms were tested using static data collection carried out in an opensky scenario. The results show decimeter level accuracy on the horizontal and vertical components of the position.
\end{abstract}

Keywords: PPP, Single-frequency, GNSS, multi-constellation

\section{Introduction}

In recent years, Precise Point Positioning (PPP) has been widely analyzed as an alternative to precise relative processing. PPP can offer decimeter to centimeter positioning accuracy without the use of base stations (Gao et al. 2002, Kouba and Héroux 2001, Zumberge et al. 1997). PPP usually employs dual-frequency code (or pseudorange - PR) and carrier phase (CP) observations, and precise satellite orbits and clock data, instead of broadcast data. PPP is suitable for precise positioning applications conducted in remote areas, without GNSS reference stations, where the use of relative GNSS, Real Time Kinematic (RTK) or network RTK, is impossible.
PPP can be applied to many commercial applications, such as offshore positioning, precision agriculture, geodetic surveys and airborne mapping.

Single-frequency PPP (SF-PPP) is becoming a popular stand-alone positioning technique, thanks to its low-cost architecture, since it does not rely on expensive dual-frequency GPS receivers and provides high positioning accuracy.

The main problem in SF-PPP is related to difficulties in estimating the CP's ambiguity. Indeed, it is necessary to mitigate errors and biases affecting the $\mathrm{CP}$ to obtain an accurate estimation of the ambiguities. The ambiguities, with the receiver coordinates, receiver clock, inter-system time offsets and tropospheric

KiG No. 32, Vol. 18, 2019, https://doi.org/10.32909/kg.18.32.6 - - 


\title{
Usporedba performansi među tehnikama preciznog pozicioniranja s jednofrekvencijskim višestrukim GNSS-om
}

\author{
Anna INNAC $1,{ }^{\star}$, Antonio ANGRISANO2, Salvatore GAGLIONE1, \\ Mario VULTAGGIO2 i Nicola CROCETTO3 \\ 1 Parthenope Università degli studi di Napoli, Dipartimento di Scienze e Tecnologie, Napulj, Italija \\ anna.innac@uniparthenope.it, salvatore.gaglione@uniparthenope.it \\ 2 Università degli Studi Giustino Fortunato, Benevento, Italija \\ a.angrisano@unifortunato.eu, m.vultaggio@unifortunato.eu \\ 3 Università degli Studi della Campania Luigi Vanvitelli, Dipartimento d'Ingegneria, Napulj, Italija \\ nicola.crocetto@unicampania.it \\ *Prepiska: anna.innac@uniparthenope.it
}

\footnotetext{
Članak je predan na engleskom jeziku. Na hrvatski ga je preveo V. Lapaine. The paper was submitted in English. It was translated into Croatian by V. Lapaine.
}

\begin{abstract}
Sažetak: Precizno pozicioniranje točke (Precise Point Positioning - PPP) je tehnika koja je u mogućnosti bilo gdje izračunati vrlo precizno pozicioniranje koristeći se jednim prijamnikom GNSS-a bez potrebe za ispravkama referentnih stanica. Postoji širok raspon algoritama za PPP s različitim modelima korekcije i strategije obrade, kako za primjene nakon obrade, tako i za one u stvarnom vremenu. PPP ovisi o točnim podatcima satelita i sata, uz upotrebu preciznih mjerenja faze nosača. Znanstvena zajednica trenutačno ispituje jednofrekvencijski PPP (SF-PPP) zahvaljujući njegovoj jeftinoj primjeni u odnosu na klasično diferencijalno pozicioniranje i višefrekvencijske nediferencirane tehnike.

Nažalost, promatrana faza nosača dvosmislena je po apriorno nepoznatom cjelobrojnom broju ciklusa, nazvanom dvosmislenost (ambiguity), što je teško razriješiti s pomoću SF prijamnika. Cilj je ovog rada bio proučiti mogućnost koju daje konstelacija višestrukih GNSS-ova primjenom na dvama široko rasprostranjenim modelima SF-PPP, na temelju različitih faza nosača i opažanih kombinacija kodova. Algoritmi su testirani korištenjem statičkog prikupljanja podataka provedenog u scenariju s otvorenim nebom. Rezultati pokazuju decimetarsku točnost u horizontalnoj i vertikalnoj komponenti položaja.
\end{abstract}

Ključne riječi: PPP, jednofrekvencijski, GNSS, višestruka konstelacija

\section{Uvod}

Posljednjih se nekoliko godina PPP široko analizira kao alternativa preciznoj relativnoj obradi. PPP može dati decimetarsku do centimetarsku položajnu točnost bez upotrebe baznih stanica (Gao i dr. 2002, Kouba i Héroux 2001, Zumberge i dr. 1997). PPP obično rabi dualni frekvencijski kod (ili pseudoraspon $\mathrm{PR})$ i opažanje nosača faze (CP) te precizne orbite satelita i podatke sata umjesto emitiranih podataka.
PPP je pogodan za primjene preciznog pozicioniranja koje se provodi u udaljenim područjima bez referentnih stanica GNSS-a, gdje je nemoguća upotreba relativnog GNSS-a, kinematike u realnom vremenu (Real Time Kinematic - RTK) ili mreže RTK. PPP se može primijeniti u mnogim komercijalnim primjenama, kao što su pozicioniranje plovila, precizna poljoprivreda, geodetska izmjera i kartiranje iz zraka.

Jednofrekvencijski PPP (SF-PPP) postaje popularna samostalna tehnika za pozicioniranje zahvaljujući 
zenith delay, comprise the set of PPP unknowns. In this study, the ambiguities are estimated as real numbers (the floating solution), as opposed to the fixed solution in which the ambiguities are estimated as integer numbers (Innac et al. 2018a, Innac et al. 2018b).

The main issue of SP-PPP is the ionospheric effect, and this remains the dominant error source in an opensky scenario. It is difficult to reduce ionospheric delay in SF receivers, due to its large variability: in fact, the range of ionospheric error varies from a few meters up to 30 meters in an ideal environment (Angrisano et al. 2013). There are two main approaches to reducing the effect of ionospheric delay using a single frequency receiver. One method consists of using ionospheric models, such as the Global Ionosphere Maps (GIM) or the Klobuchar model (Angrisano et al. 2013, Øvstedal, 2002). The other way is to use the PR and CP observables at the same frequency, to form an ionosphere-free (IF) observable, indicated as quasi-phase (QP) (Montenbruck 2003, Yunck 1993). Several studies have shown that SF-PPP based on QP can achieve centimeter-level accuracy in static mode and decimeter level accuracy in kinematic mode, significantly outperforming ionospheric mitigation models (Innac et al. 2018a, Sterle et al. 2015).

In this study, two different SF-PPP models were adopted and implemented: a model based on CP and PR measurements (called Model 1), and a model combining the QP and PR (called Model 2). Furthermore, in Model 1, Global Ionosphere Maps (GIM) from the Center for Orbit Determination in Europe (CODE) were used for the ionospheric effect on PR and CP measurements, while in Model 2, only PRs were corrected by GIMs.

In both SF-PPP models, a Kalman filter (KF) was used as the estimation technique. The $\mathrm{KF}$ was chosen since the PPP technique requires an estimation process based on cumulative knowledge of state vector to reduce the convergence period of float ambiguities (Choy 2009, Choy and Silcock 2011, Héroux 2004, Innac et al. 2018a).

The time of convergence is related to various elements such as satellite geometry and availability, the quality of the GNSS measurements and the number of parameters to estimate. Most of these items depend on the measurement scenario, and for this reason, SFPPP efficacy has mainly been demonstrated in open areas (Innac et al. 2018a).

In signal-degraded scenarios such as city centers, dense vegetation or mountainous areas that were hostile to satellite navigation, GNSS could not assure an accurate and continuous navigational solution. In these environments, the presence of obstructions around the antenna can block many GNSS signals, reducing satellite availability, weakening observation geometry, and causing, in extreme cases, gaps in navigation solutions. The multi-constellation approach improves satellite geometry and increases measurement redundancy, with consequent enhancement in terms of position accuracy and reliability in hostile scenarios. Several studies have demonstrated that the use of multi-GNSS certainly increases satellite availability but the level of accuracy depends on the operational scenario (de Bakker and Tiberius 2017, Innac et al. 2018b).

In this context, efforts have been conducted to enhance the SF-PPP performance by using multi-GNSS signals. Several authors have revealed that multiGNSS SF-PPP has the potential to increase positioning accuracy significantly and reduce convergence time, as a consequence of good satellite geometry and increased measurements availability. In (de Bakker and Tiberius 2017), results show that multi-GNSS SF-PPP outperforms GPS-only SF-PPP in particular in the case of reduced sky visibility. Also in (Li et al. 2015), various GNSS combinations are used in PPP, showing that multi-GNSS performance exceeds GPS-only ones.

Starting from the analyzed SF-PPP limits, the aim of the paper is to perform a comparison between two SF-PPP functional models (Model 1 and 2) and to verify the benefit of multi-GNSS.

GPS, GLONASS and Galileo static data were collected in open-sky scenario. The stored data were processed with the considered SF-PPP models and GNSS combinations in order to assess the possible benefits of multi-constellation and the importance of a suitable measurement model. The effectiveness of the considered configurations was verified in position domain, specifically in terms of positioning accuracy and convergence time.

In the rest of the paper, section 2 describes SFPPP functional models with the related estimation procedure and stochastic models; and sections 3 and 4 show the test and experimental results, respectively; section 5 contains the conclusions.

\section{GNSS SF-PPP Models}

Finding an optimal PPP solution requires correct and reasonable functional and stochastic models. The functional model describes the relationship between the measurements and unknowns, while the stochastic model reflects their statistical characteristics. The estimation process allows a set of desired unknowns to be obtained, starting from a set of uncertain measures, according to a proper optimization criterion (Innac 2017).

The sub-sections which follow describe two SF-PPP functional models based on different observables, and

KiG No. 32, Vol. 18, 2019, https://doi.org/10.32909/kg.18.32.6 - - - 
svojoj jeftinoj arhitekturi koja ne ovisi o skupim prijamnicima GPS-a dualne frekvencije, a koja omogućava veliku točnost pozicioniranja.

Glavni se problem SF-PPP-a odnosi na poteškoću procjene dvosmislenosti CP-a. Zaista, potrebno je ublažiti pogreške i utjecaj na CP kako bi se dobila točna procjena dvosmislenosti. Dvosmislenosti, uz koordinate prijamnika, sat prijamnika, pomaci u vremenu između sustava i troposfersko kašnjenje zenita čine skup nepoznanica PPP-a. U ovom se radu dvosmislenosti procjenjuju kao realni brojevi, suprotno fiksnom rješenju pri kojem se dvosmislenosti procjenjuju kao cijeli brojevi (Innac i dr. 2018a, Innac i dr. 2018b).

Glavni je problem SP-PPP-a ionosferni efekt koji ostaje dominantni izvor pogrešaka pri scenariju otvorenoga neba. Ionosfersko je kašnjenje teško reducirati kod SF prijamnika zbog njegove velike varijabilnosti: zapravo, raspon ionosferske pogreške varira od nekoliko metara do 30 metara u idealnim uvjetima (Angrisano i dr. 2013). Dva su glavna pristupa za reduciranje efekta ionosferskog kašnjenja upotrebom jednofrekvencijskog prijamnika. Jedna se metoda sastoji od upotrebe ionosfernih modela, kao što su Global Ionosphere Maps (GIM) ili Klobucharov model (Angrisano i dr. 2013, Øvstedal 2002). Drugi je način upotreba opažanja PR-a i CP-a na istoj frekvenciji kako bi se dobilo opažanje oslobođeno ionosfere (IF), prikazano kao kvazi-faza (QP) (Montenbruck 2003, Yunck 1993). Nekoliko je istraživanja pokazalo da SF-PPP na temelju $\mathrm{QP}$ može postići centimetarsku točnost $u$ statičkom načinu i decimetarsku točnost $u$ kinematičkom načinu, tj. dati značajno bolje rezultate od modela ublažavanja ionosfere (Innac i dr. 2018a, Sterle i dr. 2015).

U ovom su istraživanju prihvaćena i primijenjena dva različita modela SF-PPP-a: model na temelju mjerenja CP-a i PR-a (nazvan Model 1) i model koji kombinira QP i PR (nazvan Model 2). Nadalje, u Modelu 1, upotrijebljene su globalne ionosferske karte (GIM) Centra za određivanje orbita u Europi (CODE) za ionosferni efekt pri mjerenju PR-a i CP-a, dok su u Modelu 2 korigirani samo PR-ovi s pomoću GIM-ova.

U oba je modela SF-PPP-a kao tehnika procjene upotrijebljeno Kalmanovo filtriranje (KF). KF je izabran zato što tehnika PPP-a zahtijeva postupak procjene na temelju kumulativnog znanja o vektoru položaja kako bi se reduciralo vrijeme konvergencije plivajuće (floating) dvosmislenosti (Choy 2009, Choy i Silcock 2011, Héroux 2004, Innac i dr. 2018a).

Vrijeme konvergencije ovisi o različitim elementima kao što su geometrija satelita i njihova dostupnost, kvaliteta mjerenja GNSS-a i broj parametara koje treba procijeniti. Većina tih elemenata ovisi o scenariju mjerenja i zbog toga se učinkovitost SF-PPP-a uglavnom demonstrira na otvorenim područjima (Innac i dr. 2018a).

Pri scenarijima sa slabim signalima, kao što su središta gradova, gusta vegetacija ili planinska područja slabo pokrivena satelitskom navigacijom, GNSS ne može osigurati točno i neprekidno navigacijsko rješenje. U takvim situacijama prisustvo prepreka oko antene može blokirati mnogo signala GNSS-a, smanjiti dostupnost satelita, oslabiti geometriju opažanja i u ekstremnim slučajevima prouzročiti praznine u navigacijskim rješenjima. Višekonstelacijski pristup poboljšava geometriju satelita i povećava redundanciju mjerenja uz posljedično poboljšanje položajne točnosti i pouzdanosti pri lošim scenarijima. Nekoliko je istraživanja pokazalo da upotreba višestrukih GNSS-ova sigurno povećava dostupnost satelita, no razina točnosti ovisi o operativnom scenariju (de Bakker i Tiberius 2017, Innac i dr. 2018b).

U tom su kontekstu poduzeti napori da se poboljšaju svojstva SF-PPP-a upotrebom signala višestrukih GNSS-a. Nekoliko je autora otkrilo da višestruki GNSS SF-PPP ima potencijal značajnog povećanja točnosti i reduciranja vremena konvergencije kao posljedice dobre geometrije satelita i povećane dostupnosti mjerenja. Rezultati de Bakkera i Tiberiusa (2017) pokazuju da je višestruki GNSS SF-PPP bolji od samog GPS SF-PPP-a, posebno u slučaju smanjene vidljivosti neba. Također, Li i dr. (2015) upotrijebili su različite kombinacije GNSS-a u PPP-u pokazujući da višestruki GNSS premašuje one samo s GPS-om.

Polazeći od granica analiziranih SF-PPP-ova, cilj je ovoga rada usporedba dvaju modela SF-PPP-a (Modeli 1 i 2) i provjera koristi od višestrukog GNSS-a.

Statički podatci GPS-a, GLONASS-a i Galilea prikupljeni su uz scenarij otvorenog neba. Spremljeni podatci obrađeni su uz razmatrane modele SF-PPP-a i kombinacije GNSS-a kako bi se procijenile moguće koristi od višestruke konstelacije i važnost odgovarajućeg modela mjerenja. Učinkovitost razmatranih konfiguracija provjerena je u domeni položaja, posebno s obzirom na položajnu točnost i vrijeme konvergencije.

U poglavlju 2 opisani su funkcijski modeli SF-PPPa s odgovarajućim postupkom procjene i stohastički modeli, poglavlja 3 i 4 pokazuju testove i rezultate eksperimenata, a poglavlje 5 sadrži zaključke.

\section{Modeli GNSS SF-PPP-a}

Pronalaženje optimalnog rješenja za PPP zahtijeva ispravne i razborite funkcijske i stohastičke modele. Funkcijski model opisuje odnos između mjerenja i nepoznanica, dok stohastički oslikava njihova 
the chosen estimation method. In particular, Model 1 is based on PR and CP observations, while in Model 2, CPs are replaced by QPs. In this paper, the PPP approach, consisting of not-differential processing of GNSS data, is adopted. The KF method is used as an estimation technique and its formulation is given in paragraph 2.3.1, while the appropriate stochastic models for the measurements and dynamic models for the parameters are provided in 2.3.2.

\subsection{SF-PPP Model 1 (PR+CP)}

Model 1 is based on PR and CP observations, whose equations are:

$$
\begin{aligned}
P R_{f}= & \rho_{r}^{s}+c d t_{r}-c d t_{s}+\Delta I+ \\
& \Delta T+K_{P R_{f}, r}-K_{P R_{f}, s}+\varepsilon_{P R_{f}} \\
\Phi_{f}= & \rho_{r}^{s}+c d t_{r}-c d t_{s}-\Delta I+\Delta T+k_{\Phi_{f}, r}- \\
& k_{\Phi_{f}, s}+\lambda_{f} N_{f}+\lambda_{f} w+\varepsilon_{\Phi_{f}}
\end{aligned}
$$

where $P R_{f}$ is the measured PR (in $m$ ) for the frequency $f$ and $\Phi_{f}$ is the measured CP (expressed in $\mathrm{m}$ ) on the considered $f$, the indices $r$ and $s$ refer, respectively, to the receiver and satellite. The satellite-receiver distance $(\mathrm{m})$ is indicated by $\rho_{r}^{s}, d t_{r}$ and $d t_{s}$ are the receiver and satellite clock offset (sec), $\Delta I$ is the ionospheric delay, $\Delta T$ is the tropospheric delay $(\mathrm{m})$, $\lambda_{f}$ is the wavelength of the carrier, $N$ is the phase ambiguity term (in cycles), $\lambda_{f} w$ is the windup term due to the circular polarization of the electromagnetic signal. The receiver and satellite instrumental delays for the code measurements are represented by the terms $K_{P R_{f}, r}$ and $K_{P R_{f}, s}$, while the CP instrumental delay are given by $k_{\Phi_{f, r}}$ and $k_{\Phi f, s}$ Finally, the residual errors for the PR and CP measurements are represented by the terms $\varepsilon_{P R_{f}}$ and $\varepsilon_{\Phi f}$ (Angrisano et al. 2013, Innac et al. 2018a, Innac et al. 2018b).

Proper correction models were applied to reduce the effects of errors and biases that affect raw measurements. The carrier phase cycle slips were detected using the approach inspired by the algorithms developed in (Blewitt 1990), adapted for the singlefrequency code and phase combination in (Sanz Subirana et al. 2013). When a cycle slip was detected, the associated ambiguity parameter was reset.

The precise final orbit and satellite clock corrections were downloaded via the CNES website and used in data processing to mitigate the influence of orbit and satellite clock errors. Consequently, the remaining errors can be safely disregarded. These precise products, distributed in SP3 format, are given in tabular form, currently in ITRF2014, an EarthCentered, Earth-Fixed (ECEF) frame which agrees with WGS84 to within a few centimeters (Innac et al. 2018a, Innac et al. 2018b, Kouba and Héroux 2001). The precise satellite positions and clocks were interpolated via a 16-term polynomial Lagrange interpolation method to obtain the considered products at the desired epoch (Kouba and Héroux 2001).

For the atmospheric effects, GIM from the Center for Orbit Determination in Europe (CODE) were adopted to remove ionospheric delay, while Saastamoinen's hydrostatic delay correction was used to compute the tropospheric zenith dry delay (Saastamoinen 1972); instead, the wet part of tropospheric zenith delay $\left(z p d_{w}\right)$ was treated as an additional unknown parameter in the estimation process (Choy 2009, Héroux 2004, Innac et al. 2018a). The estimated delay was then mapped to lower elevation angles using Davis mapping functions (Davis et al. 1985).

The receiver code and phase instrumental delays were assimilated, respectively, in the receiver clock $\left(\widehat{d t_{r}^{G}}\right.$ in (3)) and unknown ambiguities $(\hat{N})$, thus, only the PR and CP hardware delay bias at the satellite end needed to be considered (Innac et al. 2018a, Innac et al. 2018b, Sanz Subirana et al. 2013). In particular, CODE's monthly GNSS P1-P2 Differential Code Biases (DCB) were used. P1-C1 DCB products were applied to the $\mathrm{C} 1$ code observable to emulate the $\mathrm{P} 1$ code observable, in order to adopt the satellite clock information with the C/A code (Innac et al. 2018a, Innac et al. 2018b, Sanz Subirana et al. 2013).

Other remaining biases were corrected using existing models, including the effects of $\mathrm{CP}$ windup, satellite antenna offsets and relativity (Afifi and ElRabbany 2015, Cai and Gao 2013, Cai and Gao 2009, Choy 2011, Le and Tiberius 2007, Pan et al. 2017).

In applying the described corrections, the measurement equations of the Model 1 for multi-GNSSs (GPS, GLONASS and Galileo systems) are expressed as:

$$
\begin{aligned}
& \widehat{P R}_{C 1}^{G}=\rho_{r}^{G}+c \widehat{d t}_{r}^{G}+m_{r}^{G} z p d_{w}+\varepsilon_{P R}^{G} \\
& \widehat{\Phi}_{L 1}^{G}=\rho_{r}^{G}+c \widehat{d t_{r}^{G}}+m_{r}^{G} z p d_{w}+\lambda_{L 1} \hat{N}_{L 1}^{G}+\varepsilon_{\Phi}^{G} \\
& \widehat{P R}_{E 1}^{E}=\rho_{r}^{E}+c \widehat{d t}_{r}^{G}+m_{r}^{E} z p d_{w}+c d t_{G}^{E}+\varepsilon_{P R}^{E} \\
& \widehat{\Phi}_{E 1}^{E}=\rho_{r}^{E}+c \widehat{d t}_{r}^{G}+m_{r}^{E} z p d_{w}+\lambda_{E 1} \hat{N}_{E 1}^{E}+c d t_{G}^{E}+\varepsilon_{\Phi}^{E} \\
& \widehat{P R}_{L i}^{R}=\rho_{r}^{R}+c \widehat{d t}_{r}^{G}+m_{r}^{R} z p d_{w}+c d t_{G}^{R}+\varepsilon_{P R}^{R} \\
& \widehat{\Phi}_{L i}^{R}=\rho_{r}^{R}+c \widehat{d t}_{r}^{G}+m_{r}^{R} z p d_{w}+\lambda_{L i} \hat{N}_{L i}^{R}+c d t_{G}^{R}+\varepsilon_{\Phi}^{R},
\end{aligned}
$$

KiG No. 32, Vol. 18, 2019, https://doi.org/10.32909/kg.18.32.6 — 
statistička svojstva. Postupak procjene omogućava dobivanje skupa traženih nepoznanica polazeći od skupa mjera nesigurnosti u skladu s pravilnim kriterijem optimizacije (Innac 2017).

Potpoglavlja koja slijede opisuju dva funkcijska modela SF-PPP-a na temelju različitih veličina za opažanje i odabrane metode procjene. Posebno, Model 1 se temelji na opažanjima PR-a i CP-a, dok su u Modelu 2 CP-ovi zamijenjeni QP-ovima. U ovom je radu prihvaćen pristup PPP-u koji se sastoji od nediferencijalne obrade podataka GNSS-a. Metoda KF je upotrijebljena kao tehnika procjene, a njezina je formulacija dana u odlomku 2.3.1, dok su odgovarajući stohastički modeli za mjerenja i dinamički modeli za parametre dani u 2.3.2.

\subsection{Model 1 SF-PPP-a (PR+CP)}

Model 1 se temelji na opažanjima PR-a i CP-a, čije su jednadžbe:

$$
\begin{aligned}
P R_{f}= & \rho_{r}^{s}+c d t_{r}-c d t_{s}+\Delta I+ \\
& \Delta T+K_{P R_{f}, r}-K_{P R_{f}, s}+\varepsilon_{P R_{f}} \\
\Phi_{f}= & \rho_{r}^{s}+c d t_{r}-c d t_{s}-\Delta I+\Delta T+k_{\Phi_{f}, r}- \\
& k_{\Phi_{f}, s}+\lambda_{f} N_{f}+\lambda_{f} w+\varepsilon_{\Phi_{f}}
\end{aligned}
$$

gdje je $P R_{f}$ mjerenje PR-a (u m) uz frekvenciju f, a $\Phi_{f}$ je mjerenje $\mathrm{CP}$-a (izraženo $\mathrm{u} \mathrm{m}$ ) uz razmatrano $\mathrm{f}$, indeksi $r$ i $s$ odnose se na prijamnik, odnosno satelit. Udaljenost satelit - prijamnik (m) označena je $s \rho_{r}^{s}, d t_{r} \mathrm{i}$ $d t_{s}$ su pomaci sata prijamnika i satelita (sec), $\Delta I$ je ionosferno kašnjenje, $\Delta T$ je troposfersko kašnjenje (m), $\lambda_{f}$ je valna duljina nosača, $N$ je član dvosmislenosti faze (u ciklusima), $\lambda_{f} w$ završni član zbog kružne polarizacije elektromagnetskog signala. Instrumentalna su kašnjenja prijamnika i satelita pri kodnim mjerenjima prikazana članovima $K_{P R_{f}, r}$ i $K_{P R_{f}, s}$, dok je instrumentalno kašnjenje $\mathrm{CP}$-a dano $\mathrm{s} k_{\Phi, r}$ i $k_{\Phi f, s}$ ). Konačno, pogreške odstupanja za mjerenja PR-a i CP-a prikazana su članovima $\varepsilon_{P R_{f}} \mathrm{i} \varepsilon_{\Phi_{f}}$ (Angrisano i dr. 2013, Innac i dr. 2018a, Innac i dr. 2018b).

Pogodni modeli korekcija primijenjeni su da bi se smanjili učinci pogrešaka i pristranosti koje sadrže sirova mjerenja. Klizanja ciklusa (cycle slips) nosača faze otkrivena su pri upotrebi pristupa inspiriranog algoritmima razvijenima u radu Blewitta (1990) i prilagođenima za jednofrekvencijski kod i kombinaciju faza (Sanz Subirana i dr. 2013). Kad je otkriveno klizanje ciklusa, pridruženi je parametar dvosmislenosti resetiran.
Precizne konačne orbite i korekcije sata učitane su s web-stranice CNES-a i upotrijebljene pri obradi podataka i uklanjanju utjecaja pogrešaka orbite i satelitskog sata. Prema tome, preostale se pogreške mogu slobodno zanemariti. Ti precizni proizvodi, distribuirani u formatu SP3, dani su u obliku tablice, u okviru ITRF2014 (Earth-Centered, Earth-Fixed - ECEF) koji se podudara s WGS84 do na par centimetara (Innac i dr. 2018a, Innac i dr. 2018b, Kouba i Héroux 2001). Da bi se dobio traženi podatak u željenoj epohi, precizni su položaji satelita i satovi interpolirani Lagrangeovim polinomom sa 16 članova (Kouba i Héroux 2001).

Za učinke atmosfere prihvaćen je GIM iz Center for Orbit Determination in Europe (CODE) da bi se maknulo ionosfersko kašnjenje, a Saastamoinenovo hidrostatsko kašnjenje je upotrijebljeno za računanje troposferskog zenitnog suhog kašnjenja (Saastamoinen 1972); umjesto toga vlažni dio troposferskog zenitnog kašnjenja $\left(z p d_{w}\right)$ tretiran je kao dodatni nepoznati parametar u procesu procjene (Choy 2009, Héroux 2004, Innac i dr. 2018a). Procijenjeno kašnjenje preslikano je na manje kutove elevacije s pomoću Davisovih funkcija (Davis i dr. 1985).

Kašnjenja koda prijamnika i instrumentalne faze obuhvaćena su u sat prijamnika $\left({\widehat{d t_{r}^{G}}}^{G} \mathrm{u}(3)\right)$ i nepoznatu dvosmislenost $\widehat{N}$, dakle, potrebno je razmatrati samo pristranost hardvera kašnjenja PR-a i CP-a na strani satelita (Innac i dr. 2018a, Innac i dr. 2018b, Sanz Subirana i dr. 2013). Upotrijebljeni su CODE-ovi mjesečni GNSS P1-P2 Differential Code Biases (DCB). Proizvodi P1-C1 DCB-a primijenjeni su na vrijednosti C1 koda da bi se oponašale vrijednosti $\mathrm{P} 1$ koda, kako bi se prihvatile informacije satelitskog sata s C/A kodom (Innac i dr. 2018a, Innac i dr. 2018b, Sanz Subirana i dr. 2013).

Preostale su pristranosti korigirane upotrebom postojećih modela, uključujući učinak završetka CPa, pomak satelitske antene i relativnost (Afifi i El-Rabbany 2015, Cai i Gao 2013, Cai i Gao 2009, Choy 2011, Le i Tiberius 2007, Pan i dr. 2017).

Primjenom opisanih korekcija jednadžbe mjerenja za Model 1 za višestruki GNSS (GPS, GLONASS i Galileo) izražene su ovako:

$$
\begin{aligned}
& \widehat{P R}_{C 1}^{G}=\rho_{r}^{G}+c \widehat{d t}_{r}^{G}+m_{r}^{G} z p d_{w}+\varepsilon_{P R}^{G} \\
& \widehat{\Phi}_{L 1}^{G}=\rho_{r}^{G}+c \widehat{d t_{r}^{G}}+m_{r}^{G} z p d_{w}+\lambda_{L 1} \hat{N}_{L 1}^{G}+\varepsilon_{\Phi}^{G} \\
& \widehat{P R}_{E 1}^{E}=\rho_{r}^{E}+c \widehat{d t}_{r}^{G}+m_{r}^{E} z p d_{w}+c d t_{G}^{E}+\varepsilon_{P R}^{E} \\
& \widehat{\Phi}_{E 1}^{E}=\rho_{r}^{E}+c \widehat{d t}_{r}^{G}+m_{r}^{E} z p d_{w}+\lambda_{E 1} \hat{N}_{E 1}^{E}+c d t_{G}^{E}+\varepsilon_{\Phi}^{E} \\
& \widehat{P R}_{L i}^{R}=\rho_{r}^{R}+c \widehat{d t}_{r}^{G}+m_{r}^{R} z p d_{w}+c d t_{G}^{R}+\varepsilon_{P R}^{R} \\
& \widehat{\Phi}_{L i}^{R}=\rho_{r}^{R}+c \widehat{d t}_{r}^{G}+m_{r}^{R} z p d_{w}+\lambda_{L i} \hat{N}_{L i}^{R}+c d t_{G}^{R}+\varepsilon_{\Phi}^{R},
\end{aligned}
$$


where the indices $G, R$ and $E$ stand for GPS, GLONASS and Galileo systems respectively, $r$ indicates the receiver, $\widehat{P R}$ and $\widehat{\Phi}$ are the corrected $P R$ and CP observables with C1 denoting C/A code on L1 GPS signal, E1 represents the Galileo signal having the same value of L1 GPS, and Li is the GLONASS signal in the L1 band, where the index $i$ is used for the frequency channel number. The $z_{p} d_{w}$ term corresponds to the wet part of tropospheric delay scaled by its troposphere mapping function $m_{r}^{*} ; c$ is the speed light, ${\overrightarrow{d t_{r}}}_{r}$ is the receiver clock error joined to the receiver code hardware delay, $d t_{G}^{E}$ and $d t_{G}^{R}$ are the intersystem time-offsets between the two systems as indicated by the subscripts, $\hat{N}$ is the ambiguity parameter merged to the $\mathrm{CP}$ instrumental delays associated with the receiver and satellites; $\varepsilon_{P R}^{*}, \varepsilon_{\Phi}^{*}$ are the noise terms.

The equations expressed by (3) are linearized considering the approximate values of the unknown parameters forming the SF-PPP measurement model given by the following formula in matrix form:

$$
\underline{z}=H \underline{\Delta x}+\underline{\varepsilon}
$$

where $\underline{\varepsilon}$ is the vector of the residual errors, $\underline{z}$ is the measurements vector corresponding to the difference between the measured and predicted observables, expressed as:

$\underline{z}=\left[\left(\underline{z}_{P R}^{G}\right)^{T},\left(\underline{z}_{C P}^{G}\right)^{T},\left(\underline{z}_{P R}^{E}\right)^{T},\left(\underline{z}_{C P}^{E}\right)^{T},\left(\underline{z}_{P R}^{R}\right)^{T},\left(\underline{z}_{C P}^{R}\right)^{T}\right]^{T}$

where $\underline{z}_{P R}$ and $\underline{z}_{C P}$ represent the PR and CP measurements vectors; $H$ is the design matrix defined as:

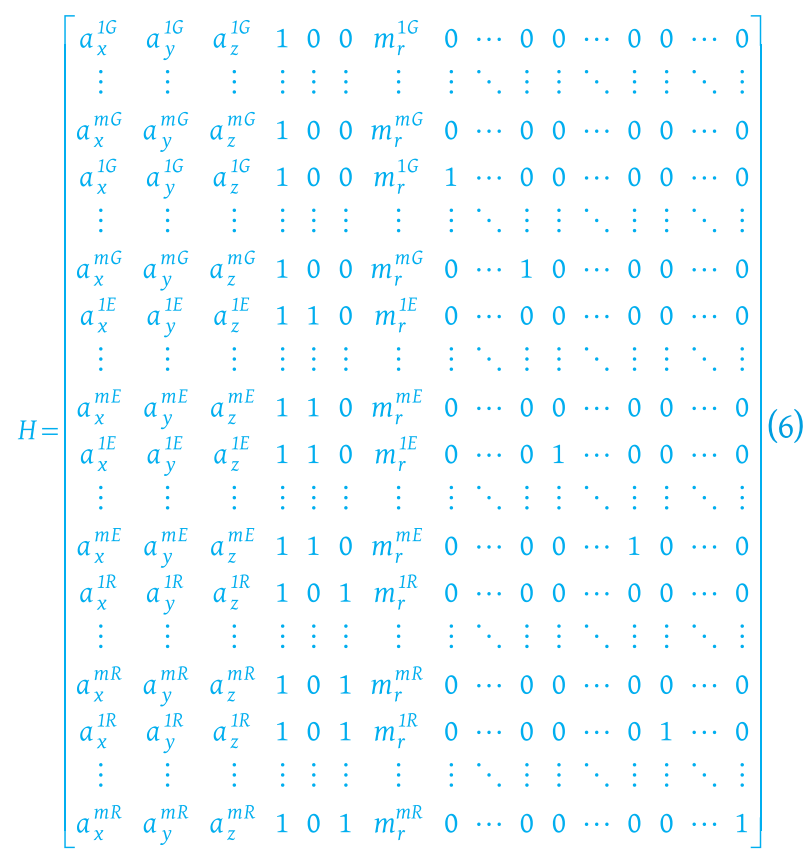

The terms $a_{x}, a_{y}$ and $a_{z}$ in (6) are the direction cosines, defined as $a_{x}=\left(x_{0}-X\right) / \rho_{0}, a_{y}=\left(y_{0}-Y\right) / \rho_{0}, a_{z}=$ $\left(z_{0}-Z\right) / \rho_{0}$, where $\rho_{0}$ is the approximate satellite-receiver distance, with $\left(x_{0}, y_{0}, z_{0}\right)$ as the approximate receiver coordinates and $(X, Y, Z)$ as the interpolated precise GNSS satellite coordinates from the SP3 file (Innac et al. 2018a, Innac et al. 2018b).

Finally, $\underline{\Delta x}$ is the state vector consisting of the increments to apply to the approximate solution and is defined as

$$
\begin{aligned}
& \underline{\Delta x}=\left[\Delta x, \Delta y, \Delta z, \Delta\left(c \widehat{d t}_{r}\right), \Delta\left(c \delta t_{E}^{G}\right), \Delta\left(c \delta t_{R}^{G}\right), \Delta\left(z p d_{w}\right),\right. \\
& \Delta\left(\lambda_{L 1} \hat{N}_{L 1}^{1 G}\right) \cdots \Delta\left(\lambda_{L 1} \hat{N}_{L 1}^{m G}\right), \Delta\left(\lambda_{E 1} \hat{N}_{E 1}^{1 E}\right) \cdots \\
& \left.\Delta\left(\lambda_{E 1} \hat{N}_{E 1}^{m E}\right), \Delta\left(\lambda_{L 1} \hat{N}_{L 1}^{1 R}\right) \cdots \Delta\left(\lambda_{L 1} \hat{N}_{L 1}^{m R}\right)\right]^{T}
\end{aligned}
$$

The unknowns in SF-PPP are the receiver coordinates, the receiver clock error, the inter-system time-offset between the two systems, the wet component of tropospheric delay and the non-integer ambiguity parameters (in meters). Furthermore, it should be underlined that the number of unknown parameters is $(m G N S S+7)$ with $m G N S S=m G+m E+$ $m R$ (where $m G, m E$ and $m R$ are respectively the number of GPS, Galileo and GLONASS measurements), while the number of equations is ( $2 * m G N S S)$. Consequently, since the redundancy is (mGNSS - 7), at least 7 mixed satellites are necessary for the solution computation. In this work, Kalman Filter (KF) was used as an estimation method to solve the measurement model for the unknown parameters.

\subsection{SF-PPP Model 2 (PR+QP)}

Starting from equations 1 and 2, and considering the different signs of ionospheric delay in the PR and $\mathrm{CP}$ observation equations, the SF ionosphere-free observable can be obtained (Choy 2011, Montenbruck 2003, Yunck 1993). Its expression is:

$$
\begin{aligned}
& Q P_{f}=\frac{P R_{f}+\Phi_{f}}{2}= \\
& \rho_{r}^{s}+c d t_{r}-c d t_{S}+\Delta T+\frac{1}{2}\left(K_{P R_{f}, r}-K_{P R_{f}, S}\right)+ \\
& \frac{1}{2}\left(k_{\Phi_{f}, r}-k_{\Phi_{f}, S}\right)+\frac{1}{2} \lambda_{f} N_{f}+\frac{1}{2} \lambda_{f} \omega+\frac{1}{2} \varepsilon_{\Phi_{f}}+\frac{1}{2} \varepsilon_{P R_{f}}
\end{aligned}
$$

The observable $Q P_{f}$ is indicated as "quasi-phase" $(\mathrm{QP})$, and is characterized by greater noise than the 
gdje su indeksi $G, R$ i $E$ za GPS, GLONASS i Galileo, $r$ označava prijamnik, $\widehat{P R} \mathrm{i} \widehat{\Phi}$ su korigirane veličine PR $\mathrm{i}$ CP uz C1 koji označava kod C/A na signalu L1 GPS-a, E1 je signal Galilea koji ima istu vrijednost kao L1 GPS-a, a Li je GLONASS-ov signal u L1, gdje je indeks $i$ upotrijebljen za broj frekvencijskog kanala. Član zpd odgovara vlažnom dijelu troposferskog kašnjenja skaliranog funkcijom troposferskog preslikavanja $m_{r}^{*} ; c$ je brzina svjetlosti, $\widehat{d t_{r}^{G}}$ je pogreška sata prijamnika spojena s kašnjenjem hardvera koda prijamni$\mathrm{ka}, d t_{G}^{E}$ i $d t_{G}^{R}$ su pomaci u vremenu unutar sustava između dvaju sustava kako je označeno donjim indeksima, $\widehat{N}$ je parametar dvosmislenosti spojen s instrumentalnim kašnjenjem $\mathrm{CP}$-a pridružen prijamniku i satelitima; $\varepsilon_{P R}^{*}, \varepsilon_{\Phi}^{*}$ su članovi šuma.

Jednadžbe (3) su linearizirane uzimajući u obzir približne vrijednosti nepoznatih parametara koji oblikuju model mjerenja SF-PPP-a i u matričnom obliku glase:

$$
\underline{z}=H \underline{\Delta x}+\underline{\varepsilon}
$$

gdje je $\underline{\varepsilon}$ vektor pogrešaka odstupanja, $\underline{z}$ je vektor mjerenja koji odgovara razlici između mjerenih i pretpostavljenih veličina izraženih kao:

$\underline{z}=\left[\left(\underline{z}_{P R}^{G}\right)^{T},\left(\underline{z}_{C P}^{G}\right)^{T},\left(\underline{z}_{P R}^{E}\right)^{T},\left(\underline{z}_{C P}^{E}\right)^{T},\left(\underline{z}_{P R}^{R}\right)^{T},\left(\underline{z}_{C P}^{R}\right)^{T}\right]^{T}$,

gdje su $\underline{z}_{P R}$ i $\underline{z}_{C P}$ vektori mjerenja PR i CP; $H$ je matrica definirana ovako:

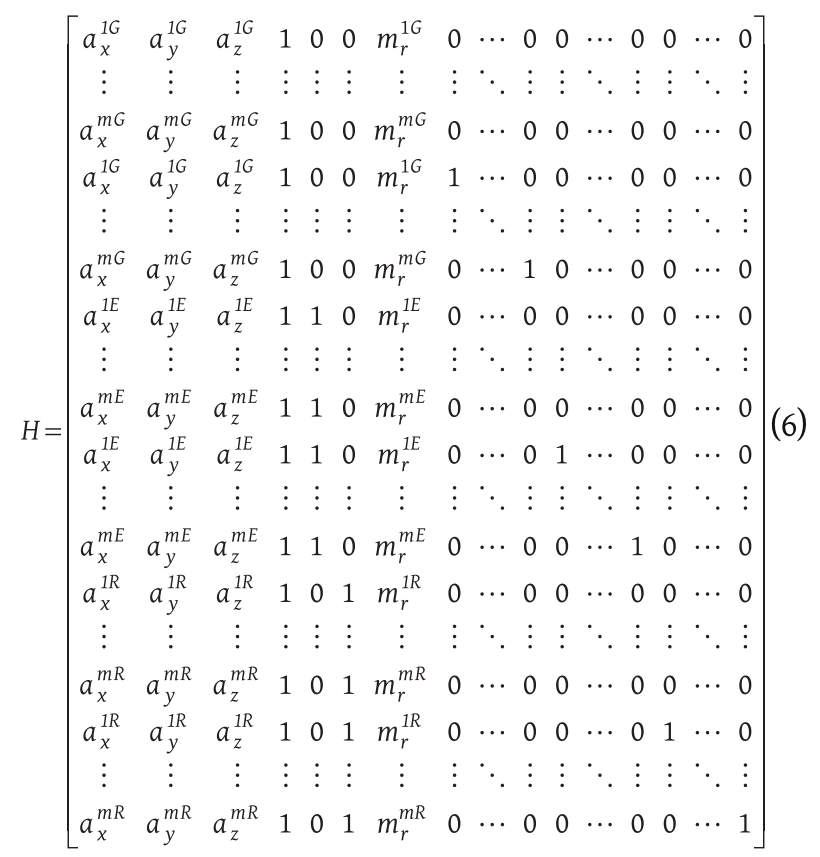

Članovi $a_{x}, a_{y}$ i $a_{z} \mathrm{u}(6)$ su smjerovi kosinusa definirani kao $a_{x}=\left(x_{0}-X\right) / \rho_{0}, a_{y}=\left(y_{0}-Y\right) / \rho_{0}, a_{z}=\left(z_{0}-Z\right) / \rho_{0}$, gdje je $\rho_{0}$ približna udaljenost između satelita i prijamnika, $\left(x_{0}, y_{0}, z_{0}\right)$ su približne koordinate prijamnika, a $(X$, $Y, Z)$ interpolirane precizne koordinate satelita iz datoteke SP3 (Innac i dr. 2018a, Innac i dr. 2018b).

Konačno, $\underline{\Delta x}$ je vektor položaja koji se sastoji od priraštaja koje treba primijeniti na približno rješenje, a definiran je ovako:

$$
\begin{aligned}
& \underline{\Delta x}=\left[\Delta x, \Delta y, \Delta z, \Delta\left(c \widehat{d t}_{r}\right), \Delta\left(c \delta t_{E}^{G}\right), \Delta\left(c \delta t_{R}^{G}\right), \Delta\left(z p d_{w}\right),\right. \\
& \Delta\left(\lambda_{L 1} \hat{N}_{L 1}^{1 G}\right) \cdots \Delta\left(\lambda_{L 1} \hat{N}_{L 1}^{m G}\right), \Delta\left(\lambda_{E 1} \hat{N}_{E 1}^{1 E}\right) \cdots \\
& \left.\Delta\left(\lambda_{E 1} \hat{N}_{E 1}^{m E}\right), \Delta\left(\lambda_{L 1} \hat{N}_{L 1}^{1 R}\right) \cdots \Delta\left(\lambda_{L 1} \hat{N}_{L 1}^{m R}\right)\right]^{T} .
\end{aligned}
$$

Nepoznanice u SF-PPP-u su koordinate prijamnika, pogreška sata prijamnika, pomak u vremenu unutar sustava između dvaju sustava, vlažna komponenta troposferskog kašnjenja i necjelobrojni parametar dvosmislenosti (u metrima). Nadalje, treba naglasiti da je broj nepoznatih parametara $m G N S S+7 \mathrm{uz} m G N S S=m G+$ $m E+m R$ (gdje su $G, m E$ i $m R$ brojevi mjerenja GPS-a, Galilea i GLONASS-a), dok je broj jednadžbi $2 * m G N S S$. Prema tome, budući da je redundancija mGNSS - 7, potrebno je najmanje 7 miješanih satelita za računanje rješenja. U ovom je radu upotrijebljen Kalmanov filter (KF) kao metoda procjene da bi se riješio model mjerenja s nepoznatim parametrima.

\subsection{Model 2 SF-PPP-a (PR+QP)}

Polazeći od jednadžbi 1 i 2 i uzimajući u obzir različite predznake ionosferskog kašnjenja za PR i CP, u jednadžbama opažanja može se dobiti veličina SF slobodna od ionosfere (Choy 2011, Montenbruck 2003, Yunck 1993). Izraz je:

$$
\begin{aligned}
& Q P_{f}=\frac{P R_{f}+\Phi_{f}}{2}= \\
& \rho_{r}^{s}+c d t_{r}-c d t_{S}+\Delta T+\frac{1}{2}\left(K_{P R_{f}, r}-K_{P R_{f}, S}\right)+ \\
& \frac{1}{2}\left(k_{\Phi_{f}, r}-k_{\Phi_{f}, S}\right)+\frac{1}{2} \lambda_{f} N_{f}+\frac{1}{2} \lambda_{f} \omega+\frac{1}{2} \varepsilon_{\Phi_{f}}+\frac{1}{2} \varepsilon_{P R_{f}} .
\end{aligned}
$$

Veličina $Q P_{f}$ je "kvazi-faza" $(Q P)$, a karakterizirana je većim šumom od mjerenja CP-a zbog utjecaja koda (Montenbruck 2003, Yunck 1993).

U Modelu 2 SF-PPP-a veličina QP se obrađuje zajedno s PR kako je opisano u potpoglavlju 2.1. Detaljnije, 
$\mathrm{CP}$ measurement because of the code influence (Montenbruck 2003, Yunck 1993).

In the SF-PPP Model 2, the QP observable is processed jointly with the PR as described in sub-section 2.1. In detail, the raw measurements are corrected as in Model 1, with the exception that ionospheric delay is removed from $\mathrm{QP}$ measures by the combination itself. After measurements correction, the SFPPP Model 2 is obtained as follow:

$$
\begin{aligned}
& \widehat{P R}_{C 1}^{G}=\rho_{r}^{G}+c \widehat{d t}_{r}^{G}+m_{r}^{G} z p d_{w}+\varepsilon_{P R}^{G} \\
& \widehat{Q P}_{L 1}^{G}=\rho_{r}^{G}+c \widetilde{d t}_{r}^{G}+m_{r}^{G} z p d_{w}+0.5 \lambda_{L 1} \widetilde{N}_{L 1}^{G}+0.5 \varepsilon_{Q P}^{G} \\
& \widehat{P R}_{E 1}^{E}=\rho_{r}^{E}+c \widehat{d t_{r}^{G}}+m_{r}^{E} z p d_{w}+c d t_{G}^{E}+\varepsilon_{P R}^{E} \\
& \widehat{Q P}_{E 1}^{E}=\rho_{r}^{E}+c \widetilde{d t}_{r}^{G}+m_{r}^{E} z p d_{w}+0.5 \lambda_{E 1} \widetilde{N}_{E 1}^{E}+c d t_{G}^{E}+0.5 \varepsilon_{Q P}^{E} \\
& \widehat{P R}_{L 1}^{R}=\rho_{r}^{R}+c \widehat{d t t}_{r}^{G}+m_{r}^{R} z p d_{w}+c d t_{G}^{R}+\varepsilon_{P R}^{R} \\
& \widehat{Q P}_{L 1}^{R}=\rho_{r}^{R}+c \widetilde{d t}_{r}^{R}+m_{r}^{R} z p d_{w}+0.5 \lambda_{L i} \widetilde{N}_{L i}^{R}+c d t_{G}^{R}+0.5 \varepsilon_{Q P}^{R}
\end{aligned}
$$

where the terms have the same meaning detailed for (3), with the exception that in SF-PPP Model 2 the expressions are also referred for QP; instead, $\widetilde{d t_{r}^{G}}$ and $\widetilde{N}$ have the same meaning but different values since they absorb different hardware delays. Indeed, the receiver code hardware delay and $\mathrm{CP}$ instrumental delays that are lumped, respectively, to the receiver clock error and ambiguities are half those determined in equations 1 and 2 . In addition, the floating ambiguity parameters are scaled by 0.5 respect to CPs.

The equations in (9) are linearized as described in sub-section 2.1 to obtain the SF-PPP measurement model that has the same form as Model 1. For Model 2, the design matrix $H(6)$ and the residual vector $\underline{\varepsilon}$ have the same expressions given in subsection 2.1. In addition, the state vector includes the same unknown parameters but the real-value ambiguities are scaled by 0.5 , while the measurement vector is redefined to include QP observables as follows:

$$
\underline{z}=\left[\left(\underline{z}_{P R}^{G}\right)^{T},\left(\underline{z}_{Q P}^{G}\right)^{T},\left(\underline{z}_{P R}^{E}\right)^{T},\left(\underline{z}_{Q P}^{E}\right)^{T},\left(\underline{z}_{P R}^{R}\right)^{T},\left(\underline{z}_{Q P}^{R}\right)^{T}\right]^{T}
$$

Also, for SF-PPP Model 2, at least 7 satellites must be visible to compute the unknown parameters that are the receiver coordinates, the receiver clock error, the inter-system time-offset between the two systems, the wet component of tropospheric delay and the non-integer ambiguity parameters. The solution is estimated using the Kalman filter method as described in subsection 2.3.

\subsection{Estimation Process}

\subsubsection{Kalman Filtering}

KF estimation is a technique commonly used in navigational applications. KF is an optimal recursive algorithm using measurements and a priori knowledge about state behavior and its discrete form is (Angrisano 2010, Cai 2009, Rabbou and El-Rabbany 2015):

$$
\begin{aligned}
& \underline{z}_{k+1}=H_{k+1} \cdot \underline{x}_{k+1}+\underline{\varepsilon}_{k+1} \\
& \underline{x}_{k+1}=\Phi_{k+1} \cdot \underline{x}_{k}+\underline{w}_{k}
\end{aligned}
$$

The measurement model in (11) is formally identical to the linearized model described in subsection 2.1, with the additional assumption of zero-mean white noise with Gaussian distribution for the measurement noise $\underline{\varepsilon}_{k}$, whose associated covariance matrix is $R_{k}$.

In the process model (12), $\Phi_{k+1}$ is the state transition matrix from epoch $k^{\text {th }}$ to $(k+1)^{\text {th }}$ and the term $w_{k}$ is the process driving noise at epoch $k^{\text {th }}$, with a covariance matrix $Q_{k}$, accounting for the uncertainty of the process model.

$\mathrm{KF}$ alternates a series of prediction and update steps to give a linear, unbiased, and minimum error variance and to compute an optimal state vector estimate. The first step involves the prediction of the state vector and the associated covariance matrix from the current to the next epoch, considered the assumed process model (Angrisano 2010). The prediction step is represented by the following equations:

$$
\begin{aligned}
& \underline{\hat{x}}_{k+1}^{-}=\Phi_{k+1, k} \underline{\hat{x}}_{k}^{+} \\
& P_{k+1}^{-}=\Phi_{k+1, k} P_{k}^{+} \Phi_{k+1, k}^{T}+Q_{k}
\end{aligned}
$$

with the superscript "+" indicating the a posteriori (corrected) quantities (i.e. after the measurement update) and the superscript "-" referring to the a priori (predicted) quantities (i.e. before the measurement update). $P_{k}$ is the covariance matrix of the state vector at epoch $t_{k}$.

The equations of the correction step, based on the measurement model, update the state vector and the associated covariance matrix as:

$$
\begin{aligned}
& \underline{\hat{x}}_{k+1}^{+}=\underline{\hat{x}}_{k+1}^{-}+K_{k+1}\left(\underline{z}_{k+1}-H_{k+1} \hat{\underline{x}}_{k+1}^{-}\right) \\
& P_{k+1}^{+}=\left(I-K_{k+1} H_{k+1}\right) P_{k+1}^{-}
\end{aligned}
$$


sirova su mjerenja popravljena kao u Modelu 1, s izuzetkom ionosferskog kašnjenja koje je kombinacijom maknuto iz mjerenja QP-a. Nakon korekcije mjerenja Model 2 SF-PPP-a je sljedeći:

$$
\begin{aligned}
& \widehat{P R}_{C 1}^{G}=\rho_{r}^{G}+c \widehat{d t}_{r}^{G}+m_{r}^{G} z p d_{w}+\varepsilon_{P R}^{G} \\
& \widehat{Q P}_{L 1}^{G}=\rho_{r}^{G}+c \widetilde{d t}_{r}^{G}+m_{r}^{G} z p d_{w}+0,5 \lambda_{L 1} \widetilde{N}_{L 1}^{G}+0,5 \varepsilon_{Q P}^{G} \\
& \widehat{P R}_{E 1}^{E}=\rho_{r}^{E}+c \widehat{d t}_{r}^{G}+m_{r}^{E} z p d_{w}+c d t_{G}^{E}+\varepsilon_{P R}^{E} \\
& \widehat{Q P}_{E 1}^{E}=\rho_{r}^{E}+c \widetilde{d t}_{r}^{G}+m_{r}^{E} z p d_{w}+0,5 \lambda_{E 1} \widetilde{N}_{E 1}^{E}+c d t_{G}^{E}+0,5 \varepsilon_{Q P}^{E} \\
& \widehat{P R}_{L 1}^{R}=\rho_{r}^{R}+c \widehat{d t}_{r}^{G}+m_{r}^{R} z p d_{w}+c d t_{G}^{R}+\varepsilon_{P R}^{R} \\
& \widehat{Q P}_{L 1}^{R}=\rho_{r}^{R}+c \widetilde{d t}_{r}^{R}+m_{r}^{R} z p d_{w}+0,5 \lambda_{L i} \widetilde{N}_{L i}^{R}+c d t_{G}^{R}+0,5 \varepsilon_{Q P}^{R},
\end{aligned}
$$

gdje članovi imaju isto značenje kao u (3), osim što se u Modelu 2 SF-PPP-a izrazi također odnose na QP; umjesto toga, $\widetilde{d t_{r}^{G}}$ i $\widetilde{N}$ imaju isto značenje, ali različite vrijednosti jer apsorbiraju različita kašnjenja hardvera. Zaista, kašnjenje hardvera koda prijamnika i instrumentalno kašnjenje CP-a su skupljeni u pogrešku sata prijamnika, a dvosmislenosti su polovica onih određenih jednadžbama 1 i 2 . Osim toga, parametri plivajuće dvosmislenosti skalirani su s 0,5 $\mathrm{u}$ odnosu na CP-ove.

Jednadžbe (9) su linearizirane kao što je opisano u potpoglavlju 2.1 da bi se dobio model mjerenja SFPPP-a koji ima isti oblik kao Model 1. Za Model 2, matrica $H(6)$ i vektor odstupanja $\varepsilon$ imaju iste izraze dane u potpoglavlju 2.1. Osim toga, vektor položaja sadrži iste nepoznate parametre, no realne vrijednosti dvosmislenosti skalirane su s 0,5 , dok je vektor mjerenja redefiniran kako bi sadržavao veličine $Q P$ kako slijedi:

$$
\underline{z}=\left[\left(\underline{z}_{P R}^{G}\right)^{T},\left(\underline{z}_{Q P}^{G}\right)^{T},\left(\underline{z}_{P R}^{E}\right)^{T},\left(\underline{z}_{Q P}^{E}\right)^{T},\left(\underline{z}_{P R}^{R}\right)^{T},\left(\underline{z}_{Q P}^{R}\right)^{T}\right]^{T}
$$

Također, za Model 2 SF-PPP-a mora biti vidljivo najmanje 7 satelita da bi se izračunalo nepoznate parametre koji su koordinate prijamnika, pogreška sata prijamnika, pomak vremena unutar sustava između dvaju sustava, vlažna komponenta troposferskog kašnjenja i necjelobrojni parametri dvosmislenosti. Rješenje je procijenjeno upotrebom metode Kalmanova filtriranja kako je opisano $u$ potpoglavlju 2.3 .

\subsection{Postupak procjene}

\subsubsection{Kalmanovo filtriranje}

Procjenjivanje KF-om je tehnika koja se uobičajeno rabi u navigacijskim primjenama. KF je optimalan rekurzivni algoritam koji se koristi mjerenjima i a priori znanjem o ponašanju stanja, a njegova diskretna forma je (Angrisano 2010, Cai 2009, Rabbou i El-Rabbany 2015):

$$
\begin{aligned}
& \underline{z}_{k+1}=H_{k+1} \cdot \underline{x}_{k+1}+\underline{\varepsilon}_{k+1} \\
& \underline{x}_{k+1}=\Phi_{k+1} \cdot \underline{x}_{k}+\underline{w}_{k} .
\end{aligned}
$$

Model mjerenja (11) je formalno identičan lineariziranom modelu opisanom $u$ potpoglavlju $2.1, \mathrm{~s}$ dodatnom pretpostavkom o sredini nula bijelog šuma s Gaussovom razdiobom za šum mjerenja $\underline{\varepsilon}_{k}$, čija je matrica kovarijanci $R_{k}$.

U modelu postupka (12), $\Phi_{k+1}$ je matrica prijelaza stanja iz $k$-te epohe $u(k+1)^{\text {th }}$, a član $\underline{w}_{k}$ je šum proizveden procesom $u$ k-toj epohi s matricom kovarijanci $Q_{k}$, izračunanom za nesigurnost modela procesa.

KF alternira niz pretpostavki i ažuriranih stanja da bi dao linearnu, nepristranu procjenu optimalnog stanja vektora s minimalnom varijancom. Prvi korak uključuje pretpostavku o stanju vektora i pridruženu matricu kovarijance iz tekuće u sljedeću epohu, uzimajući u obzir pretpostavljeni model procesa (Angrisano 2010). Korak pretpostavke prikazan je sljedećim jednadžbama:

$$
\begin{aligned}
& \underline{\hat{x}}_{k+1}^{-}=\Phi_{k+1, k} \underline{\hat{x}}_{k}^{+} \\
& P_{k+1}^{-}=\Phi_{k+1, k} P_{k}^{+} \Phi_{k+1, k}^{T}+Q_{k}
\end{aligned}
$$

s gornjim indeksom "+" koji pokazuje a posteriori (popravljene) veličine (tj. nakon ažuriranih mjerenja), a donji indeks “-" odnosi se na a priori (pretpostavljene) veličine (tj. prije ažuriranja mjerenja). $P_{k}$ je matrica kovarijanci položaja vektora u epohi $t_{k}$.

Jednadžbe koraka za korekciju, utemeljene na modelu mjerenja, ažuriraju vektor stanja i pridruženu matricu kovarijanci:

$$
\begin{aligned}
& \hat{\hat{x}}_{k+1}^{+}=\underline{\hat{x}}_{k+1}^{-}+K_{k+1}\left(\underline{z}_{k+1}-H_{k+1} \underline{\hat{x}}_{k+1}^{-}\right) \\
& P_{k+1}^{+}=\left(I-K_{k+1} H_{k+1}\right) P_{k+1}^{-}
\end{aligned}
$$


where $K_{k+1}$ is the Kalman gain matrix at $t_{k+1}$ epoch and its expression is:

$$
K_{k+1}=P_{k+1}^{-} H_{k+1}^{T}\left(H_{k+1} P_{k+1}^{-} H_{k+1}^{T}+R_{k+1}\right)^{-1}
$$

The Kalman gain matrix is a weighting factor about how the new information contained in the innovation vector $\left(\underline{z}_{k+1}-H_{k+1} \underline{\hat{x}}_{k+1}^{-}\right)$influences the final state vector estimate.

\subsubsection{Stochastic Modeling}

To employ the KF method, the stochastic behavior of both measurements and process errors needs to be defined. The measurement errors are assumed with zero mean and covariance matrix $R_{k}$.

For both SF-PPP models, the measurements are assumed to be uncorrelated (as subsequently detailed), so $R_{k}$ is a diagonal matrix, whose nonzero elements are the PR and CP (or QP depending on the considered measurement model) error variances. In this paper, a variance model depending on both satellite elevation and $C / N_{0}$ is used and its expression is (Innac 2017, Realini and Reguzzoni 2013):

$$
\sigma_{i}^{2}= \begin{cases}\frac{1}{\sin ^{2}\left(E l_{i}\right)} \Gamma_{i} & \text { if } C / N_{0}<s_{1} \\ 1 & \text { if } C / N_{0} \geq s_{1}\end{cases}
$$

Where

$$
\Gamma_{i}=10^{-\frac{C / N_{0}-s_{1}}{B}}\left[\left(\frac{A}{10^{-\frac{s_{0}-s_{1}}{B}}}-1\right) \frac{C / N_{0}-s_{1}}{s_{0}-s_{1}}+1\right]
$$

and $s_{1}$ is the threshold. If the measurement $C / N_{0}$ is higher than the threshold, it is considered good and the weight is set to 1 . The proposed values for the constant $s_{1}, s_{0}, B$ and $A$ can be found in (Realini and Reguzzoni 2013). The variances of GPS and Galileo PRs are computed using the model in (18), while GLONASS PRs are down-weighted due to its lower accuracy compared to GPS or Galileo systems. Instead, the variance of $\mathrm{CP}$ is empirically scaled by a $1 / 100$ factor with respect to the corresponding GNSS PRs (Choy 2009, Innac et al. 2018b).

As it is well known from the literature, the relationship between PR and QP measures is given by:

$$
\left[\begin{array}{l}
P R \\
Q P
\end{array}\right]=F \cdot\left[\begin{array}{l}
P R \\
C P
\end{array}\right]
$$

where $F$ is a function matrix defined as

$$
F=\left[\begin{array}{cc}
1 & 0 \\
0.5 & 0.5
\end{array}\right]
$$

Given the covariance matrix of PR and CP error $(R)$ as described previously, and using error propagation law, the covariance of $\mathrm{PR}$ and $\mathrm{QP}$ observations reads:

$$
R_{\text {new }}=F \cdot R \cdot F^{T}
$$

However, by performing the described stochastic model for SF-PPP Model 2, the results would show behavior very similar to Model 1 and a long convergence time. For this reason, several experiments were carried out showing that the performance of Model 2 could improve in position domain if the measurements (PR and $\mathrm{QP}$ ) are assumed to be uncorrelated. Furthermore, the variances of PRs are given by (18), while the variance of $\mathrm{QP}$ is empirically scaled by a 1/50 factor (Innac et al. 2018a, Innac et al. 2018b). The process model describes the kinematic behavior of the unknowns.

As described in section 2.2, the unknown parameters of the proposed SF-PPP models include the threedimensional position coordinates, the receiver clock offset, inter-system time-offset between the two systems, the wet component of tropospheric delay and the non-integer ambiguity parameters. The static position coordinates, the two inter-system time-offsets and ambiguity parameters are considered as constants and their transition matrix is an identity matrix. The receiver clock offset and zenith wet tropospheric delay parameters are modeled as Random Walk (RW) processes in the Kalman filter (Cai 2009). The transition matrix of these parameters is still an identity matrix and the process noise matrices for these parameters are given as follows, respectively:

$$
\begin{aligned}
& Q_{d t_{r}}=q_{d t_{r}} \cdot \Delta \mathrm{t} \\
& Q_{z p d_{w}}=q_{z p d_{w}} \cdot \Delta \mathrm{t}
\end{aligned}
$$

where $\Delta t$ is the sample rate, $q_{d t r}$ is the the spectral density of the receiver clock set to $9 \cdot 10^{-3} \mathrm{~m}^{2} / \mathrm{sec}$, and $q_{z p d_{w}}$ is the spectral density of the zenith wet tropospheric delay that is equal to $7.7 \cdot 10^{-12} \mathrm{~m}^{2} / \mathrm{sec}$ (Innac et al. 2018a, Innac et al. 2018b).

KiG No. 32, Vol. 18, 2019, https://doi.org/10.32909/kg.18.32.6 - 
gdje je $K_{k+1}$ dobivena Kalmanova matrica u epohi $t_{k+1}$, a njezin izraz je:

$$
K_{k+1}=P_{k+1}^{-} H_{k+1}^{T}\left(H_{k+1} P_{k+1}^{-} H_{k+1}^{T}+R_{k+1}\right)^{-1}
$$

Dobivena Kalmanova matrica je težinski faktor koji opisuje utjecaj nove informacije sadržane u novom vektoru $\left(\underline{z}_{k+1}-H_{k+1} \hat{\widehat{x}}_{k+1}^{-}\right)$na procjenu konačnog stanja vektora.

\subsubsection{Stohastičko modeliranje}

Da bi se primijenila metoda KF, potrebno je definirati stohastičko ponašanje mjerenja i pogrešaka. Pretpostavljamo da pogreške mjerenja imaju sredinu nula i matricu kovarijanci $R_{k}$.

Za oba modela SF-PPP-a pretpostavljamo da su mjerenja nekorelirana (kako je u nastavku detaljnije opisano), tako da je $R_{k}$ dijagonalna matrica čiji su nenul elementi varijance pogrešaka PR-a i CP-a (ili QP-a u ovisnosti o razmatranom modelu mjerenja). U ovom je članku upotrijebljen model varijance $u$ ovisnosti o elevaciji satelita i $C / N_{0}$, a formula je (Innac 2017, Realini i Reguzzoni 2013):

$$
\sigma_{i}^{2}= \begin{cases}\frac{1}{\sin ^{2}\left(E l_{i}\right)} \Gamma_{i} & \text { if } C / N_{0}<s_{1} \\ 1 & \text { if } C / N_{0} \geq s_{1}\end{cases}
$$

gdje

$$
\Gamma_{i}=10^{-\frac{C / N_{0}-s_{1}}{B}}\left[\left(\frac{A}{10^{-\frac{s_{0}-s_{1}}{B}}}-1\right) \frac{C / N_{0}-s_{1}}{s_{0}-s_{1}}+1\right]
$$

a $s_{1}$ je prag. Ako je mjerenje $C / N_{0}$ veće od praga, smatra se dobrim i težina se uzima 1 . Vrijednosti konstanti $s_{1}, s_{0}, B$ i A mogu se naći u članku (Realini i Reguzzoni 2013). Varijance PR-ova za GPS i Galileo izračunane su upotrebom modela (18), dok su onima za GLONASS smanjene težine zbog manje točnosti u usporedbi sa sustavima GPS i Galileo. Umjesto toga, varijanca $\mathrm{CP}-\mathrm{a}$ je empirijski skalirana faktorom 1/100 u odnosu na odgovarajuće PR-ove GNSS-a (Choy 2009, Innac i dr. 2018b).

Kao što je dobro poznato iz literature, odnos između mjera PR i QP je dan sa:

$$
\left[\begin{array}{l}
P R \\
Q P
\end{array}\right]=F \cdot\left[\begin{array}{l}
P R \\
C P
\end{array}\right]
$$

gdje je $F$ matrica definirana ovako:

$$
F=\left[\begin{array}{cc}
1 & 0 \\
0,5 & 0,5
\end{array}\right]
$$

Za zadanu matricu kovarijanci od PR-a i pogrešku $\mathrm{CP}(R)$ kako je prethodno opisano, primjenom zakona o prirastu pogrešaka kovarijance opažanja PR i QP su:

$$
R_{\text {new }}=F \cdot R \cdot F^{T}
$$

Međutim, rezultat izvođenja opisanog stohastičkog modela za Model 2 SF-PPP-a pokazat će ponašanje vrlo slično Modelu 1 i vrlo dugo vrijeme konvergencije. Zbog toga je provedeno nekoliko eksperimenata koji su pokazali da izvođenje Modela 2 može poboljšati domenu položaja ako se pretpostavi da su mjerenja (PR i QP) nekorelirana. Nadalje, varijance PR-ova dane su sa (18), dok je varijanca od QP empirijski skalirana s faktorom 1/50 (Innac i dr. 2018a, Innac i dr. 2018b). Model procesa opisuje kinematičko ponašanje nepoznanica.

Kao što je opisano u poglavlju 2.2, nepoznati parametri predloženih modela SF-PPP-a sadrže trodimenzionalne koordinate položaja, pomak sata prijamnika, pomak u vremenu unutar sustava između dvaju sustava, vlažnu komponentu troposferskog kašnjenja i necjelobrojne parametre dvosmislenosti. Statičke položajne koordinate, dva pomaka u vremenu unutar sustava i parametri dvosmislenosti smatraju se konstantama i njihova matrica prijelaza je jedinična matrica. Pomak sata prijamnika i parametri zenitnog vlažnog troposferskog kašnjenja modelirani su kao procesi slučajne šetnje (Random Walk - RW) u Kalmanovu filteru (Cai 2009). Prijelazna je matrica tih parametara još uvijek jedinična matrica, a matrice za obradu šuma za te parametre su dani kako slijedi:

$$
\begin{aligned}
& Q_{d t r}=q_{d t r} \cdot \Delta t \\
& Q_{z p d_{w}}=q_{z p d_{w}} \cdot \Delta \mathrm{t},
\end{aligned}
$$

gdje je $\Delta t$ stopa uzorka, $q_{d t r}$ spektralna gustoća sata prijamnika postavljena na $9 \cdot 10^{-3} \mathrm{~m}^{2 /} \mathrm{sec}$, a $q_{z p d_{w}}$ je spektralna gustoća zenitnog vlažnog troposferskog kašnjenja koja je jednaka 7,7·10-12 $\mathrm{m}^{2} / \mathrm{sec}$ (Innac i dr. 2018a, Innac i dr. 2018b).

\section{Testovi}

Dana 23. svibnja 2018. devet sati su prikupljani podatci GNSS-a u statičkom načinu; antena je stavljena na krov zgrade u Arzanu (Napulj), iznad kojega 


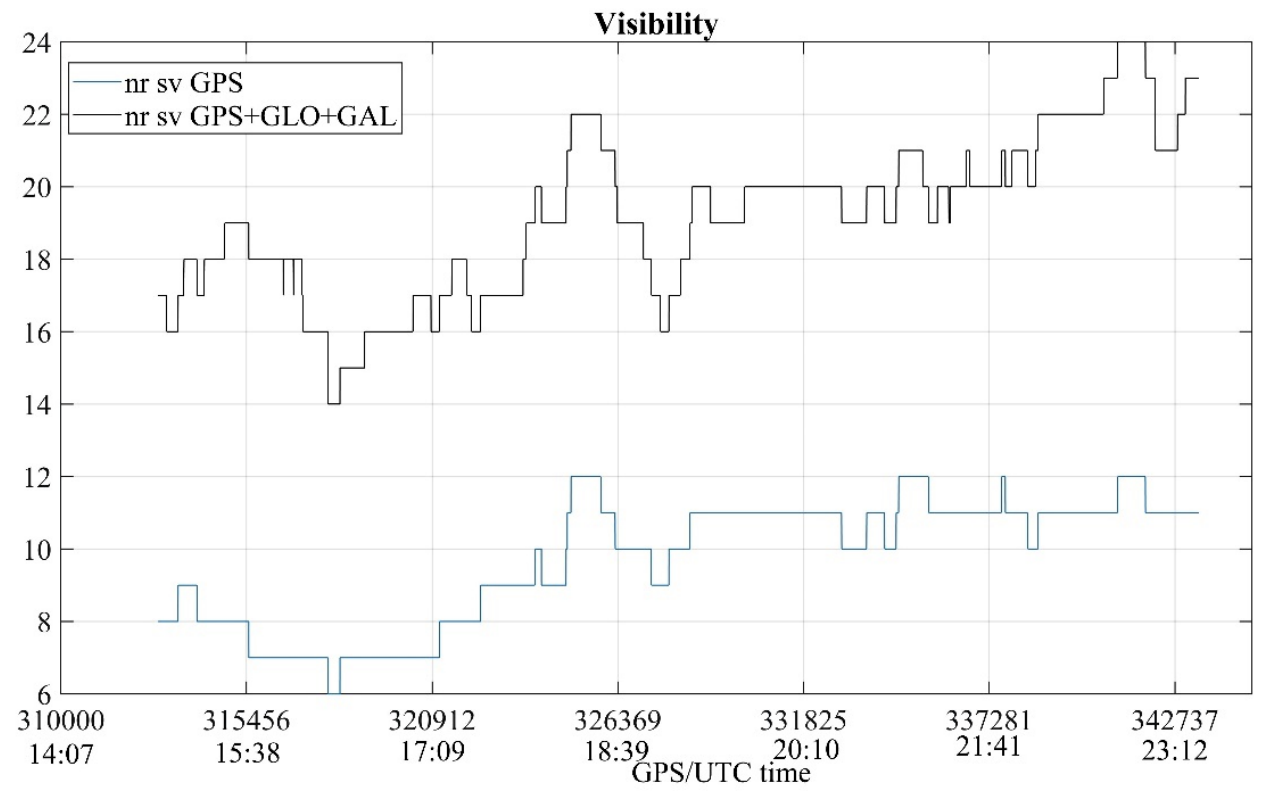

Fig. 1 Number of available GNSS satellites during data collection.

Slika 1. Broj dostupnih satelita GNSS-a za vrijeme prikupljanja podataka.

\section{Tests}

On 23 May 2018, GNSS data were collected for 9 hours in static mode; the antenna was placed on the roof of a building in Arzano (Naples), which is an open-sky environment. A Teseo III receiver by STMicroelectronics (Datasheet of Teseo III 2017) was connected to the antenna to track GPS, Galileo and GLONASS measurements with a sampling rate of 1 Hz. The data were processed in PPP modes combining the GPS, GLONASS and the Galileo observations; the analyzed configurations were:

- GPS, GPS/GLO, GPS/GAL, GPS/GLO/GAL for SF-PPP Model 1 (using PR and CP measurements);

- GPS, GPS/GLO, GPS/GAL, GPS/GLO/GAL for SF-PPP Model 2 (using PR and QP measurements).

In order to process GNSS data in PPP, a customized position, velocity and timing (PVT) algorithm, developed in MatLab ${ }^{\circledR}$ environment, was used in this research. All the software belongs to a Toolbox developed by PANG (PArthenope Navigation Group http://pang. uniparthenope.it). The main inputs of the algorithm are GNSS observables, i.e. pseudorange and carrier-phase, and GNSS ephemerides (broadcast e final precise products). The ephemerides were used to obtain satellite position and clock offset, while the raw observables were corrected for several error sources as described in section 2 . The performance of the considered configurations was compared and analyzed in position domain; the known coordinates of the antenna (surveyed with topographic method and consistent with ITRF14) were used as a reference for error computation. The adopted figures of merit were Root Mean Square (RMS), mean and maximum errors for both horizontal and vertical components of the position.

\section{Discussion}

In this section, the performance of the configurations, previously described, is assessed. One of the aims of this analysis is to evaluate the behaviors of the considered SF-PPP models, especially the one using $\mathrm{QP}$ (described in 2.2). The other main aim is to compare GPS-only and multi-GNSS strategies in order to underline the impact of multi-GNSS for PPP techniques in terms of accuracy and convergence time.

The data collection was carried out in an open sky scenario with no obstructions near the antenna. This was confirmed by the analysis of satellite availability and geometry, reported in Figure 1 and Table 1, where several combinations of GNSSs are considered.

In Figure 1, the number of visible GPS satellites (blue line) and the total number of visible GPS, Glonass and Galileo satellites (black line) during the test are plotted. The figure shows that the number of available GNSS satellites is very high, varying from 14 to 24 with a mean value of 19; the improvement in terms of

KiG No. 32, Vol. 18, 2019, https://doi.org/10.32909/kg.18.32.6 - - 
Tablica 1. Vrijednosti PDOP-a za PPP uz različite kombinacije GNSS-a.

Table 1 PDOP values for PPP mode considering different GNSS combinations.

\begin{tabular}{llll}
$\begin{array}{l}\text { Configurations } \\
\text { Konfiguracije }\end{array}$ & $\begin{array}{l}\text { Mean } \\
\text { Sredina } \\
\text { PDOP/ PDOP }\end{array}$ & $\begin{array}{l}\text { Max } \\
\text { Maks. }\end{array}$ & $\begin{array}{l}\text { Min } \\
\text { Min. }\end{array}$ \\
\hline GPS & $1.30 / 1,30$ & $3.84 / 3,84$ & $0.87 / 0,87$ \\
GPS/GAL & $3.93 / 3,93$ & $10.49 / 10,49$ & $2.17 / 2,17$ \\
GPS/GLO & $3.43 / 3,43$ & $10.12 / 10,12$ & $2.06 / 2,06$ \\
GPS/GAL/GLO & $2.99 / 2,99$ & $5.92 / 5,92$ & $1.91 / 1,91$
\end{tabular}

je otvoreno nebo. Prijamnik Teseo III tvrtke STMicroelectronics (Datasheet of Teseo III 2017) spojen je na antenu za praćenje mjerenja GPS-a, Galilea i GLONASS-a uz stopu uzrokovanja od $1 \mathrm{~Hz}$. Podatci su obrađeni na PPP načine kombinirajući opažanja GPSa, GLONASS-a i Galilea. Analizirane su konfiguracije:

- GPS, GPS/GLO, GPS/GAL, GPS/GLO/GAL za Model 1 SF-PPP-a (upotrebom mjerenja PR-a i CP-a)

- GPS, GPS/GLO, GPS/GAL, GPS/GLO/GAL za Model 2 SF-PPP-a (upotrebom mjerenja PR-a i QP-a).

Da bi se obradili podatci GNSS-a $u$ PPP- $u$, $u$ ovom je istraživanju primijenjen algoritam razvijen u programu MatLab ${ }^{\circledR}$ za određivanje brzine i vremena (PVT). Cijeli softver pripada Toolboxu koji je razvio PANG (PArthenope Navigation Group - http://pang. uniparthenope.it). Glavni ulazni podatci za algoritam su veličine GNSS-a, tj. pseudoraspon i nosač faze, i efemeride GNSS-a (emitiranje konačnih preciznih proizvoda). Efemeride su upotrijebljene za dobivanje položaja satelita i pomaka sata, dok su sirova opažanja popravljena za nekoliko izvora pogrešaka kako je opisano u poglavlju 2. Izvođenje razmatranih konfiguracija uspoređeno je i analizirano $u$ domeni položaja; poznate koordinate antene (izmjerene topografskom metodom i sukladne s okvirom ITRF14) upotrijebljene su kao referentne za računanje pogrešaka. Prihvaćene vrijednosti su srednja kvadratna pogreška (Root Mean Square - RMS), srednje i maksimalne pogreške za horizontalnu i vertikalnu komponentu položaja.

\section{Rasprava}

U ovom se poglavlju bavimo prethodno opisanim konfiguracijama. Jedan od ciljeva te analize je procjena ponašanja razmatranih modela SF-PPP-a, posebno onoga koji rabi QP (opisano u 2.2). Drugi je cilj usporedba samo GPS-a i višestruke strategije GNSS-a kako bi se podvukao utjecaj višestrukog GNSS-a za tehnike PPP-a s obzirom na točnost i vrijeme konvergencije.

Prikupljanje podataka obavljeno je uz scenarij otvorenoga neba bez smetnji u blizini antene. To je potvrđeno analiziranjem dostupnosti satelita, što se vidi sa slike $1 \mathrm{i}$ iz tablice 1 , gdje su razmatrane različite kombinacije GNSS-a.

Na slici 1 plavom su linijom prikazani vidljivi sateliti GPS-a, a crnom linijom ukupan broj vidljivih satelita GPS-a, GLONASS-a i Galilea za vrijeme testiranja. Slika prikazuje da je broj dostupnih satelita GNSS-a vrlo velik, varira između 14 i 24 sa srednjom vrijednosti 19; poboljšanje dostupnosti mjerenja višekonstelacijskog pristupa $u$ odnosu na sami GPS je očigledno.

PDOP (Position Dilution of Precision) je upotrijebljen kao indeks kvalitete geometrije satelita. Vrijednosti PDOP-a dobivene su iz matrice upotrijebljene u Modelu 1 SF-PPP-a kao što je označeno u (6); ponašanje PDOP-a sumirano je u tablici 1 s pomoću maksimalne, minimalne i srednje vrijednosti za različite konfiguracije GNSS-a.

Za vrijeme prikupljanja podataka srednja vrijednost PDOP-a za konfiguracije GPS PPP-a bila je 1,3 u rasponu od 0,9 do 3,8. Za usporedbu, vrijednosti PDOPa za GPS/GAL i GPS/GLO PPP bile su veće u usporedbi s drugim konfiguracijama, $u$ rasponu od 2 do 10 sa srednjom vrijednosti 3,5. Geometrija satelita s višestrukom strategijom GNSS PPP-a bila je slabija od drugih pokazujući različiti trend: PDOP vrijednosti padaju s brojem vidljivih satelita uključujući različite sustave GNSS-a. Razlog tome je uključivanje velikog broja mjerenja nosača faze što je utjecalo na računanje DOP-a.

Položajna točnost predloženih strategija SF-PPPa analizirana je $u$ tablici 2, gdje su prikazane odgovarajuće vrijednosti.

Tablica 2 pokazuje da obje metode obrade SFPPP-a daju decimetarsku točnost za horizontalnu i vertikalnu komponentu. Osim toga, za sve konfiguracije GNSS-a, Model 2 PPP-a, uključujući PR i QP, daje bolje rezultate $\mathrm{u}$ usporedbi s Modelom 1 PPP-a $\mathrm{u}$ kojem su obrađeni PR-ovi i CP-ovi. Posebno, uspoređujući višestruke konfiguracije (GPS/GLO/GAL), horizontalni se RMS smanjuje od oko 0,43 metra za Model 1 GPS/GLO/GAL PPP-a na oko 0,24 metra za Model 2, dok vertikalni RMS pada za oko 0,14 metara. Upotreba opažanja QP u Modelu 2 smanjuje horizontalne i vertikalne srednje pogreške za oko 0,26 i 0,41 metara u odnosu na Model 1.

Nadalje, uspoređujući konfiguracije Modela 2 PPPa, očito je da GPS ima najbolje ponašanje u usporedbi s ostalima uglavnom na vertikalnoj komponenti. 
measurements availability of the multi-constellation approach with respect to GPS-only case is evident.

The Position Dilution of Precision (PDOP) was used as an index of the quality of the satellite geometry. PDOP values were obtained from the design matrix used in SF-PPP Model 1 as indicated by (6); the behavior of PDOP is summarized in Table 1 in terms of the maximum, minimum and mean values for different GNSS configurations.

During data collection, the mean value of PDOP for GPS PPP configurations was 1.3, ranging from 0.9 to 3.8. In comparison, the values of PDOP for GPS/GAL and GPS/GLO PPP were the highest compared to the other configurations, ranging from 2 to 10 with a mean of 3.5. The satellite geometry with multi-GNSS PPP strategy was weaker compared to the others, showing a different trend: PPP PDOP values increased with the number of visible satellites, including different GNSS systems. This was due to the inclusion of a high number of carrier phase measurements, which influenced the DOP computation.

The positioning accuracy of the proposed SF-PPP strategies is analyzed in Table 2 where the considered figures of merit are summarized.

Table 2 shows that both SF-PPP processing methods provide decimeter level accuracy on horizontal and vertical components. In addition, for all GNSS configurations, PPP Model 2, including PR and QP, have better performance compared to PPP Model 1 in which PRs and CPs are processed. In particular, comparing multi-GNSS (GPS/GLO/GAL) configurations, horizontal RMS decreases from circa 0.43 meters for GPS/GLO/GAL PPP Model 1 to circa 0.24 meters for Model 2, while vertical RMS drops by about 0.14 meters. The use of QP observations in the Model 2 reduces the horizontal and vertical mean errors of circa 0.26 and 0.41 meters with respect to Model 1 .

Furthermore, comparing PPP Model 2 configurations, it is evident that GPS has the best behavior compared to the others, mainly on the vertical component. However, GPS and GPS/GAL PPP Model 2 show very similar performance, as can be seen from the horizontal and vertical mean error and RMS values. In contrast, the accuracy positioning slightly decreases for GPS/GLO Model 2, with a worsening of decimeter order for all analyzed figures of merit. Finally, the multi-GNSS configuration has a performance comparable to GPS and GPS/GAL PPP Model 2 except for vertical RMS and maximum errors, so including GLONASS does not influence the positioning accuracy of multi-constellation, thanks to the reduction of its measurement variance.
The same conclusions can be drawn comparing the performance between different GNSSs for PPP Model 1. Indeed, the best results were obtained for GPS and GPS/Galileo PPP Model 1 in terms of all considered figures of merit, while GPS/GLO/GAL and GPS/GLO PPP Model 1 settings showed higher indicator values on both positioning error components, confirming the lower accuracy of GLONASS observables.

A qualitative analysis is shown in the following figures to underline the performance differences between PPP Model 1 and 2 configurations. In addition, to show the benefits of multi-GNSS in the position domain, Figure 2 displays the temporal variation of horizontal and vertical positioning errors only for GPS PPP Model 1 (magenta line) and 2 (blue line), GPS/GLO/GAL PPP Model 1 (black line) and 2 (green line).

From the figure, it can be seen that GPS and GPS/GLO/GAL PPP Model 2 display the best behavior on both vertical and horizontal components as confirmed by the figures of merit summarized in Table 2 . Furthermore, enhancement can be observed for GPS/GLO/GAL PPP Model 2 at the beginning of the data collection and between 18:00 and 20:10 mainly on the horizontal plane. This is related to the increased number of visible satellites that led significantly to enhance PPP positioning accuracy and reduced the initial convergence time. Furthermore, the research results indicate that even with the worsening of satellite geometry, the position convergence time is mainly dependent on enhancement in terms of satellite availability.

In contrast, GPS and GPS/GLO/GAL PPP Model 1 have very similar performance and both configurations are characterized by very long converge times. The position solutions obtained using Model 1 were not able to reach steadily a specific accuracy level during the total data collection. This result demonstrates the contribution of the QP observable, allowing the elimination of ionospheric effects combining the code and carrier phase observations.

To analyze the average behavior of positioning errors computed using the considered processing modes, Figure 3 provides the empirical Cumulative Distribution Function (CDF) of horizontal and vertical position errors for GPS PPP Model 2 (yellow line), GPS PPP Model 1 (green line), GPS/GLO/GAL PPP Model 2 (magenta line), GPS/GLO/GAL PPP Model 1 (black line).

Figure 3 confirms that GPS-only and GPS/GLO/ GAL configurations perform at very similar levels for both SF-PPP processing modes. The results clearly

KiG No. 32, Vol. 18, 2019, https://doi.org/10.32909/kg.18.32.6 - - 

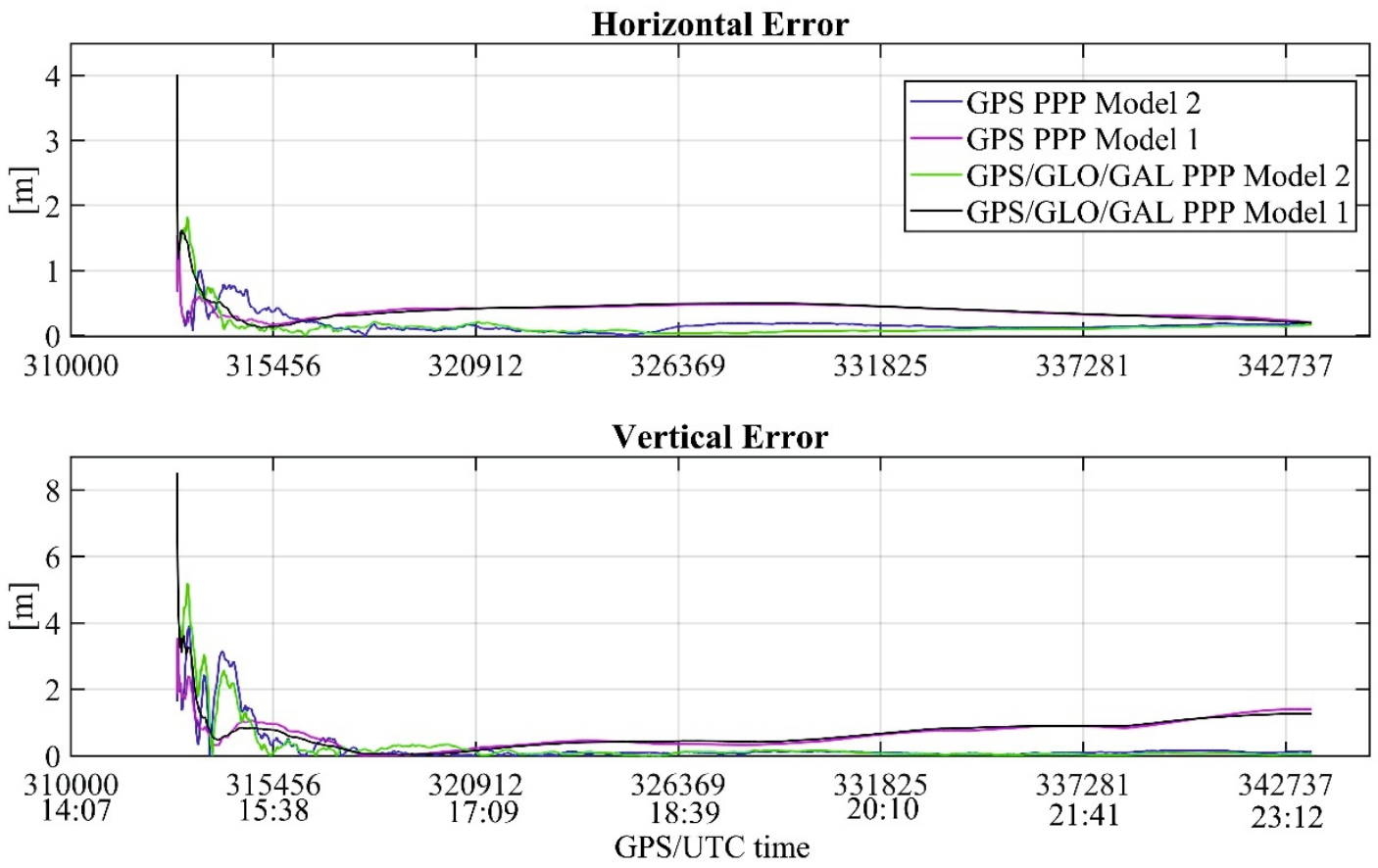

Slika 2. Horizontalne i vertikalne položajne pogreške kao funkcije vremena za Model 1 GPS PPP-a (ljubičasta/magenta linija) i 2 (plava linija), Model 1 GPS/GLO/GAL PPP-a (crna linija) i 2 (zelena linija). Fig. 2 Horizontal and vertical positioning errors as functions of the time for GPS PPP Model 1 (magenta line) and 2 (blue line), GPS/GLO/GAL PPP Model 1 (black line) and 2 (green line).

Tablica 2. Horizontalne $(H)$ i vertikalne (Up) položajne pogreške dobivene upotrebom nekoliko GNSS-ova uz dva načina PPP-a.

Table 2 Horizontal (H) and Vertical (Up) positioning errors obtained using several GNSSs in the two type of PPP modes.

\begin{tabular}{|c|c|c|c|c|c|c|}
\hline \multirow{3}{*}{$\begin{array}{l}\text { Configurations } \\
\text { Konfiguracije }\end{array}$} & \multirow{2}{*}{\multicolumn{2}{|c|}{$\begin{array}{l}\text { Mean Error }[\mathrm{m}] \\
\text { Srednja pogreška }[\mathrm{m}]\end{array}$}} & \multirow{2}{*}{\multicolumn{2}{|c|}{$\begin{array}{l}\mathrm{RMS}[\mathrm{m}] \\
\mathrm{RMS}[\mathrm{m}]\end{array}$}} & \multirow{2}{*}{\multicolumn{2}{|c|}{$\begin{array}{l}\text { Max Error }[\mathrm{m}] \\
\text { Maksimalna pogreška }[\mathrm{m}]\end{array}$}} \\
\hline & & & & & & \\
\hline & $\mathrm{H}$ & Up & $\mathrm{H}$ & Up & $\mathrm{H}$ & Up \\
\hline GPS PPP Model 2 & $0.17 / 0,17$ & $0.25 / 0,25$ & $0.22 / 0,22$ & $0.60 / 0,60$ & $1.43 / 1,43$ & $3.92 / 3,92$ \\
\hline GPS PPP Model 1 & $0.38 / 0,38$ & $0.64 / 0,64$ & $0.39 / 0,39$ & $0.76 / 0,76$ & $1.55 / 1,55$ & $3.56 / 3,56$ \\
\hline GPS/GAL PPP Model 2 & $0.20 / 0,20$ & $0.20 / 0,20$ & $0.27 / 0,27$ & $0.54 / 0,54$ & $1.42 / 1,42$ & $4.17 / 4,17$ \\
\hline GPS/GAL PPP Model 1 & $0.40 / 0,40$ & $0.59 / 0,59$ & $0.41 / 0,41$ & $0.72 / 0,72$ & $1.49 / 1,49$ & $2.18 / 2,18$ \\
\hline GPS/GLO P PPP Model 2 & $0.41 / 0,41$ & $0.51 / 0,51$ & $0.69 / 0,69$ & $1.26 / 1,26$ & $5.47 / 5,47$ & $6.63 / 6,63$ \\
\hline GPS/GLO PPP Model 1 & $0.48 / 0,48$ & $0.74 / 0,74$ & $0.65 / 0,65$ & $1.01 / 1,01$ & $5.92 / 5,92$ & $7.78 / 7,78$ \\
\hline GPS/GLO/GAL PPP Model 2 & $0.13 / 0,13$ & $0.26 / 0,26$ & $0.24 / 0,24$ & $0.69 / 0,69$ & $3.62 / 3,62$ & $7.30 / 7,30$ \\
\hline GPS/GLO/GAL PPP Model 1 & $0.39 / 0,39$ & $0.67 / 0,67$ & $0.43 / 0,43$ & $0.83 / 0,83$ & $4.02 / 4,02$ & $8.53 / 8,53$ \\
\hline
\end{tabular}

Međutim, Model 2 GPS PPP-a i GPS/GAL PPP-a pokazuju vrlo slične rezultate, što se može vidjeti iz srednjih pogrešaka i vrijednosti RMS-a za horizontalnu i vertikalnu komponentu. Nasuprot tome, položajna točnost lagano pada za Model 2 GPS/GLO s pogoršanjem reda decimetra za sve analizirane vrijednosti. Konačno, višestruka konfiguracija GNSS-a daje rezultate usporedive s Modelom 2 GPS PPP-a i GPS/GAL PPP-a, osim za vertikalni RMS i maksimalne pogreške, pa uključivanje GLONASS-a ne utječe na položajnu točnost višestruke konstelacije zahvaljujući smanjenju njegove varijance mjerenja. 

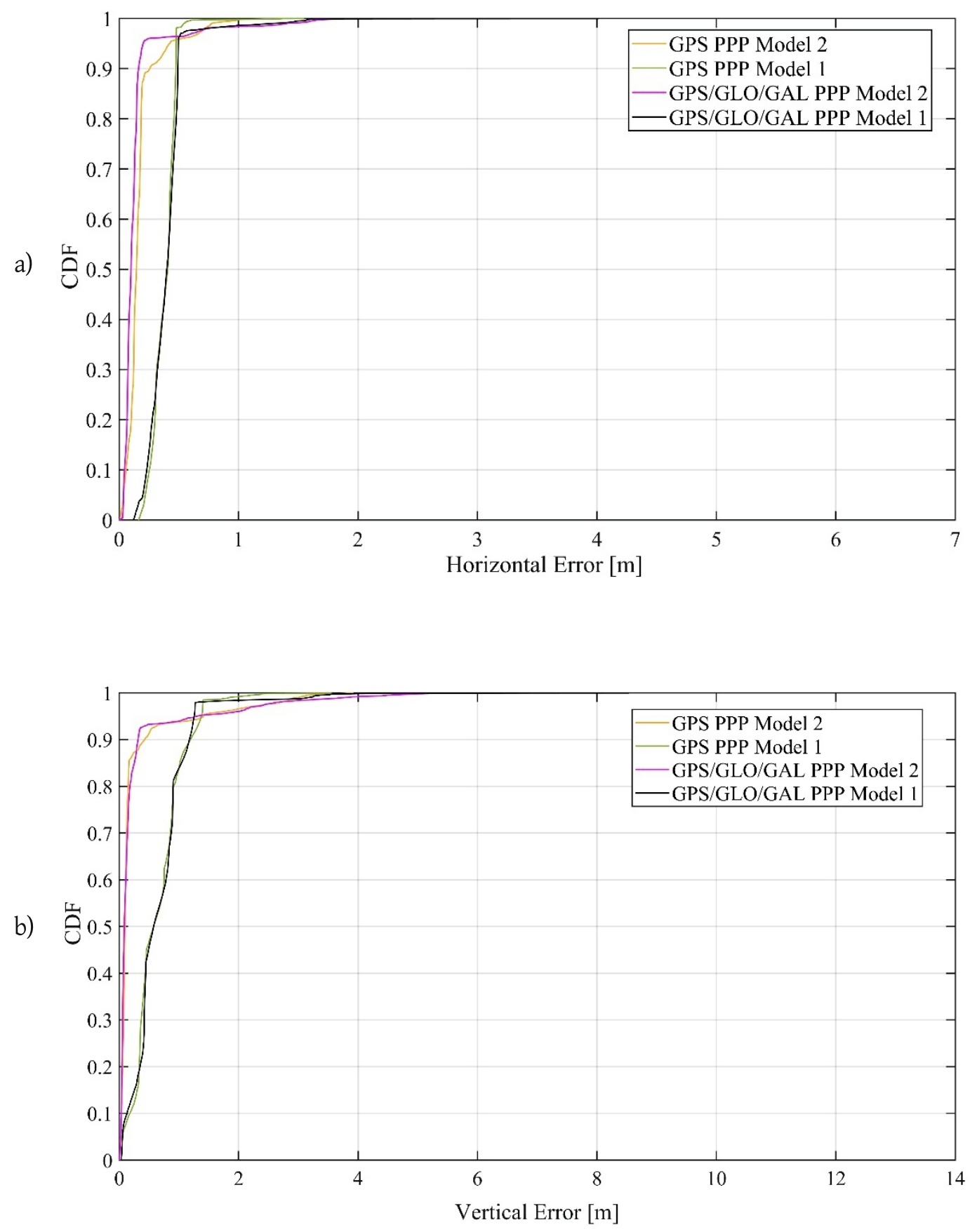

Slika 3. Ponašanje CDF-a horizontalne (a) i vertikalne pogreške položaja uspoređujući sljedeće konfiguracije: Model 2 GPS PPP-a (žuta linija), Model 1 GPS PPP-a (zelena linija), Model 2 GPS/GLO/GAL PPP-a (ljubičasta/magenta linija), Model 1 GPS/GLO/GAL PPP-a (crna linija).

Fig. 3 CDF behavior of horizontal (a) and vertical positioning errors comparing the following configurations: GPS PPP Model 2 (yellow line), GPS PPP Model 1 (green line), GPS/GLO/GAL PPP Model 2 (magenta line), GPS/GLO/GAL PPP Model 1 (black line). 
Isti se zaključci mogu izvući iz usporedbe različitih GNSS-ova za Model 1 PPP-a. Zaista, najbolji su rezultati dobiveni za Model 1 GPS PPP-a i GPS/ Galileo PPP-a u odnosu na sve razmatrane vrijednosti, dok postavke Modela 1 GPS/GLO/GAL i GPS/ GLO PPP-a pokazuju veće vrijednosti za obje komponente položajnih pogrešaka, potvrđujući manju točnost GLONASS-a.

Kako bi se istaknuli rezultati razlika između konfiguracija za Modele 1 i 2 PPP-a, na sljedećim je slikama prikazana kvalitativna analiza. Osim toga, da bi se pokazala korist od višestrukog GNSS-a u položajnoj domeni, slika 2 prikazuje varijaciju u vremenu za horizontalne i vertikalne položajne pogreške samo za Model 1 GPS PPP-a (ljubičasta/magenta linija) i Model 2 (plava linija), Model 1 GPS/GLO/GAL PPP-a (crna linija) i 2 (zelena linija).

Sa slike 2 može se vidjeti da Model 2 za GPS i GPS/GLO/GAL PPP prikazuju najbolje ponašanje i za vertikalnu i za horizontalnu komponentu, što je u skladu s podatcima u tablici 2. Nadalje, poboljšanje se može uočiti na Modelu 2 za GPS/GLO/GAL PPP na početku prikupljanja podataka i između 18:00 i 20:10 uglavnom $u$ horizontalnoj ravnini. To se odnosi na povećani broj vidljivih satelita koji je vodio prema značajnom poboljšanju točnosti PPP-a i smanjio početno vrijeme konvergencije. Osim toga, rezultati istraživanja upućuju na to da, čak i uz slabljenje geometrije satelita, vrijeme položajne konvergencije uglavnom ovisi o poboljšanju dostupnosti satelita.

Nasuprot tome, Model 1 GPS PPP-a i GPS/GLO/ GAL PPP-a daju vrlo slične rezultate i obje konfiguracije imaju vrlo duga vremena konvergencije. Rješenja položaja dobivena Modelom 1 nije bilo moguće dobiti stabilno uz specifičnu razinu točnosti za vrijeme prikupljanja svih podataka. Taj rezultat demonstrira doprinos veličine $Q P$, koji omogućava eliminaciju ionosfernog učinka kombinirajući opažanja koda i nosača faze.

Da bi se analiziralo srednje ponašanje pogrešaka položaja izračunano upotrebom razmatranih načina obrade, slika 3 daje empirijsku funkciju kumulativne razdiobe (Cumulative Distribution Function - CDF) horizontalnih i vertikalnih položajnih pogrešaka za Model 2 GPS PPP-a (žuta linija), Model 1 GPS PPP-a (zelena linija), Model 2 GPS/GLO/GAL PPP-a (ljubičasta/magenta linija), Model 1 GPS/GLO/GAL PPP-a (crna linija).

Slika 3 potvrđuje da konfiguracije samo GPS i GPS/ GLO/GAL daju vrlo slične razine za oba modela obrade SF-PPP-a. Rezultati jasno potvrđuju korist upotrebe veličine $\mathrm{QP}$, oslobođene ionosfere iz Modela $2 \mathrm{PPP}-\mathrm{a}$, uglavnom kad se kombiniraju različiti GNSS-ovi.

\section{Zaključci}

U ovom su članku analizirani rezultati dvaju različitih funkcijskih modela za SF-PPP i uspoređeni su rezultati. Riječ je o modelu utemeljenom na opažanjima PR-a i CP-a (Model 1 SF-PPP-a) i modelu utemeljenom na opažanjima QP-a i PR-a (Model 2 SF-PPP-a). Razmatrani su višestruki sustavi GNSS-a kako bi se poboljšali rezultati SF-PPP-a u pogledu točnosti, dostupnosti satelita i vremena konvergencije.

Rezultati SF-PPP-a uspoređeni su upotrebom opažanja GPS-a, Galilea i GLONASS-a i spremljeni kao statičan skup podataka dobiven u okolini otvorenoga neba. Eksperimentalni su rezultati demonstrirali da oba modela SF-PPP-a daju submetarsku točnost za horizontalnu i vertikalnu komponentu. Za sve konfiguracije GNSS-a strategija Modela 2 PPP-a pokazala je bolje rezultate $\mathrm{u}$ usporedbi s Modelom 1 PPP-a, koji je bio karakteriziran vrlo dugim vremenom konvergencije. Taj je trend podržao primjenu opažanja QP-a u obradi SFPPP-a kako bi se smanjio učinak ionosfernog kašnjenja.

U pogledu utjecaja tehnika višestrukih GNSS-a za PPP, moguće je zaključiti da u scenariju otvorenoga neba samo GPS PPP i višestruke konfiguracije GNSS-a daju vrlo slične rezultate u domeni položaja, dok je poboljšanje vremena konvergencije očigledno, uglavnom za postavku Modela 1 višestrukog GNSS PPP-a.

Razmatrani pristupi SF-PPP-a mogu biti učinkovita alternativa klasičnom apsolutnom načinu pozicioniranja kad se zahtijeva veća točnost; posebno, kombinacija opažanja oslobođenih ionosfere (QP) s PR-ovima višestruke konstelacije GNSS-a daje prednost samostalnom, točnom i isplativom načinu, primjenjivom na jednofrekvencijske prijamnike GNSS-a s masovnog tržišta. Konačno, SF-PPP je kandidat za zamjenu relativnog pozicioniranja u udaljenim područjima, gdje je istodobno dopuštena manja degradacija u smislu performansi.

\section{Zahvale}

Ovo je istraživanje podržano financiranjem osnovnih aktivnosti vezanih uz istraživanje (Funding for basic activities related to research - FFABR) uvedenim Zakonom 232/2016, i također je uvršteno u okvir DORA - Deployable Optics for Remote sensing Applications DORA (ARS01_00653), projekt što ga financira Ministarstvo obrazovanja, sveučilišta i istraživanja - Nacionalni operativni program (Ministero dell'Istruzione, dell'Università e della Ricerca - Programma Operativo Nazionale - MIUR - PON) "Istraživanje \& Inovacije / PNR 2015-2020". Autori zahvaljuju Domenicu Di Graziji i STMicroelectronics Srl za opremu upotrijebljenu u istraživanju. 
confirm the benefit of using the SF-ionosphere-free observable (QP) adopted in the PPP Model 2, mainly when different GNSSs are combined.

\section{Conclusions}

In this paper, two different functional models for SF-PPP are analyzed and their positioning results compared: a model based on PR and CP observations (SF-PPP Model 1) and a model based on QP and PR observations (SF-PPP Model 2). To improve SF-PPP performance in terms of accuracy, satellite availability and convergence time, multiple GNSS systems are considered.

SF-PPP results were compared using GPS, Galileo and GLONASS observations, and stored via a static data collection carried out in an open-sky environment. The experimental results demonstrated that both SFPPP models gave a submeter level accuracy on horizontal and vertical components. For all GNSS configurations, the PPP Model 2 strategy showed better performance compared to the PPP Model 1, which was characterized by a very long convergence time. This trend endorsed the use of QP observations in SF-PPP processing to reduce the effect of ionospheric delay.

Regarding the impact of multi-GNSS for PPP techniques, it is possible to conclude that, in an open-sky scenario, GPS-only and multi-GNSS PPP configurations have very similar outputs in position domain, while enhancement in term of convergence time is evident, mainly for multi-GNSS PPP Model 1 setup.

The considered SF-PPP approaches may be an effective alternative to the classical absolute positioning mode when higher accuracy positioning is required; in particular, the combination of the SF-ionosphere-free observable (QP) with PRs from multi-GNSS constellation provides the advantages of a stand-alone, accurate and cost-efficient positioning mode, implementable on a mass-market single frequency GNSS receiver. Finally, SF-PPP is a candidate for substitute relative positioning in remote areas, while allowing for minor degradation in terms of performance.

\section{Acknowledgments}

This research was supported by funding for basic activities related to research (FFABR) introduced by Act 232/2016, and was also included in the framework of DORA - Deployable Optics for Remote sensing Applications DORA" (ARS01_00653), a project funded by MIUR PON "Research \& Innovation"/PNR 2015-2020".

The authors wish to thank Domenico Di Grazia and STMicroelectronics Srl for providing the equipment used in the research.

\section{References / Literatura}

Afifi A, El-Rabbany A (2015) An improved model for single-frequency gps/galileo precise point positioning. Positioning, vol. $6 \mathrm{n}$. 02, p. 7

Angrisano A, Gaglione S, Gioia C, Massaro M, Troisi S (2013) Benefit of the NeQuick Galileo version in GNSS single-point positioning, International Journal of Navigation and Observation

Angrisano A (2010) GNSS/INS integration methods. PhD Thesis, Parthenope University of Naples, Naples, Italy

BDS-ICD: BeiDou Navigation Satellite System (BDS) Signal In Space Interface Control Document (SIS ICD) (2012) Open Service Signal B1I, version 1.0, December, China Satellite Navigation Office

Blewitt G (1990) An Automatic Editing Algorithms for GPS Data. Geophysical Research Letters, vol. 17, no. 3, 199-202

Cai C (2009) Precise Point Positioning using dual-frequency GPS and GLONASS measurements. In Masters Abstracts International, vol. 48, no. 3, p. 172

Cai C, Gao Y (2013) Modeling and assessment of combined GPS/GLONASS precise point positioning. GPS solutions, vol. 17, no. 2, 223-236 
Cai C, Gao Y (2009) A combined GPS/GLONASS navigation algorithm for use with limited satellite visibility. Journal of Navigation, vol. 62 , no. $04,671-685$

Choy S (2011) High accuracy precise point positioning using a single frequency GPS receiver. Journal of Applied Geodesy, vol. 5, no. 2, 59-69

Choy S, Silcock D (2011) Single frequency ionosphere-free precise point positioning: a cross-correlation problem? Journal of geodetic science, vol. 1, no. 4, 314-323

Choy S (2009) Investigation into the accuracy of single frequency precise point positioning (PPP), PhD Thesis, RMIT University, Australia

Datasheet of Teseo III by STMicroelectronics available at http://www.st.com/en/evaluation-tools/evb-t3.html (2017)

Davis JL, Herrinch TA, Shapiro II, Rollers AEE, Elgered G (1985) Geodesy by radio interferometry: Effects of atmospheric modeling errors on estimates of baseline length" Radio science, vol. 20, n. 6, 1593-1607

de Bakker PF, Tiberius C (2017) Real-time multi-GNSS single-frequency precise point positioning. GPS Solutions 2017, vol. 21, no. 4, 1791-1803

Gao Y, Shen X (2002) A New Method for Carrier Phase Based Precise Point Positioning, Navigation, Journal of the Institute of Navigation, vol. 49, no. 2

Héroux P (2004) Products and applications for Precise Point Positioning-Moving towards real-time. ION GNSS 2004, LongBeach CA, September

Innac A, Gaglione S, Troisi S, Angrisano A (2018a) A proposed fault detection and exclusion method applied to multi-GNSS singlefrequency PPP. In 2018 European Navigation Conference (ENC), 129-139

Innac A, Gaglione S, Angrisano A (2018b) Multi-GNSS Single Frequency Precise Point Positioning. In IEEE International Workshop on Metrology for the Sea, 8-10 October, 2018, Bari, Italy. Doi: 10.1109/MetroSea.2018.8657857

Innac A (2001) Fuzzy techniques applied to GNSS for quality assessment and reliability testing in difficult signal scenarios, PhD Thesis, Department of Sciences and technologies, Parthenope University of Naples

Kouba J, Héroux P (2001) Precise point positioning using IGS orbit and clock products. GPS solutions, vol. 5, no. 2, 12-28 Le $A Q$, Tiberius C (2007) Single-frequency precise point positioning with optimal filtering. GPS Solutions, vol. 11, no. 1, 61-69

Li X, Zhang X, Ren X, Fritsche M, Wickert J, Schuh H (2015) Precise positioning with current multi-constellation global navigation satellite systems: GPS, GLONASS, Galileo and BeiDou. Scientific reports, vol. 5, pp. 8328

Montenbruck 0 (2003) Kinematic GPS Positioning of LEO Satellites using lonosphere-Free Single Frequency Measurements, Aerospace Science and Technology, vol. 7, 396-405

Navcen.uscg.gov. U.S. Coast Guard Navigation Center. [online] Available at: http://www.navcen.uscg.gov/ [Accessed March 2019]. Øvstedal 0 (2002) Absolute positioning with single-frequency GPS receivers. GPS Solutions, vol. 5, no. 4, 33-44

Pan L, Zhang X, Liu J, Li X (2017) Performance evaluation of single-frequency precise point positioning with GPS, GLONASS, BeiDou and Galileo. The Journal of Navigation, vol. 70, no. 3, 465-482

Rabbou M A, El-Rabbany A (2015) PPP accuracy enhancement using GPS/GLONASS observations in kinematic mode. Positioning, vol. 6, no. 1, p. 1

Realini E Reguzzoni M (2013) GoGPS: Open source software for enhancing the accuracy of low-cost receivers by single-frequency relative kinematic positioning. Measurement Science and Technology, vol. 24, no. 11

Saastamoinen J (1972) Atmospheric correction for the troposphere and stratosphere in radio ranging satellites. The use of artificial satellites for geodesy, vol. 15, 247-251

Sanz Subirana J, Juan Zornoza JM, Hernandez-Pajares M (2013) GNSS Data Processing, Vol. I: Fundamentals and Algorithms. ESA communications, ESTEC TM-23/l, Noordwijk, the Netherlands

Sterle 0, Stopar B, Prešeren PP (2015) Single-frequency precise point positioning: an analytical approach. Journal of Geodesy, vol. 89 , no. 8, 793-810

Yunck T (1993) Coping with the atmosphere and ionosphere in precise satellite and ground positioning, Geophysical Monograph, vol. 73 , no. 13, 1-16

Zumberge JF, Heflin MB, Jefferson DC, Watkins MM, Webb FH (1997) Precise Point Processing for the Efficient and Robust Analysis of GPS Data from Large Networks. Journal of Geophysical Research, vol. 102, 5005-5017 